\title{
Annonaceae in the Western Pacific: geographic patterns and four new species
}

\author{
Ian M. TURNER ${ }^{1, *} \&$ Timothy M.A. UTTERIDGE ${ }^{2}$ \\ ${ }^{1,2}$ Royal Botanic Gardens, Kew, Richmond, Surrey, TW9 3AE, UK. \\ *Corresponding author: i.turner@kew.org \\ ${ }^{2}$ Email: t.utteridge@,kew.org
}

\begin{abstract}
The taxonomy and distribution of Pacific Annonaceae are reviewed in light of recent changes in generic delimitations. A new species of the genus Monoon from the Solomon Archipelago is described, Monoon salomonicum I.M.Turner \& Utteridge sp. nov., together with an apparently related new species from New Guinea, Monoon pachypetalum I.M.Turner \& Utteridge sp. nov. The confirmed presence of the genus in the Solomon Islands extends the generic range eastward beyond New Guinea. Two new species of Huberantha are described, Huberantha asymmetrica I.M.Turner \& Utteridge sp. nov. and Huberantha whistleri I.M.Turner \& Utteridge sp. nov., from the Solomon Islands and Samoa respectively. New combinations are proposed: Drepananthus novoguineensis (Baker f.) I.M.Turner \& Utteridge comb. nov., Meiogyne punctulata (Baill.) I.M.Turner \& Utteridge comb. nov. and Monoon merrillii (Kaneh.) I.M.Turner \& Utteridge comb. nov. One neotype and four lectotypes are designated. The geographic patterns exhibited by nine native Annonaceae genera, that range in the Pacific beyond New Guinea, are discussed.
\end{abstract}

Keywords. Drepananthus, Huberantha, Meiogyne, Monoon, Samoa, Solomon Islands.

Turner I.M. \& Utteridge T.M.A. 2017. Annonaceae in the Western Pacific: geographic patterns and four new species. European Journal of Taxonomy 339: 1-44. https://doi.org/10.5852/ejt.2017.339

\section{Introduction}

There has been considerable change in the classification of the large tropical family the Annonaceae over recent decades (Chatrou et al. 2012). An area for which this has been particularly marked is the islands of the Pacific north and east of New Guinea. In this region (here taken as the Solomon Archipelago and beyond but not including the Bismarck Archipelago) the realignment of genera and the correction of faulty generic placements have led to name changes in a relatively high proportion of the native species. This reorganisation has bearing on the geographical ranges of a number of genera which have not yet been analysed in detail. The purpose of this study was to investigate the distribution patterns of the native Annonaceae genera in the Western Pacific. The currently accepted scenario for colonisation of this region by Annonaceae genera is one of dispersal from West Malesia to East Malesia, Australia and the Pacific, probably in the Miocene (5-23 Ma), during periods of relatively low sea levels resulting in larger and more closely spaced stepping stones that facilitated such migration. This has been inferred from molecular phylogenies and estimated divergence times in the Annonaceae genera Meiogyne 
(Thomas et al. 2012), Pseuduvaria Miq. (Su \& Saunders 2009) and Uvaria (Zhou et al. 2012). Johnson et al. (2013) suggested that the Xylopia species in New Caledonia may include pre-Oligocene relict taxa. However, in general, Xylopia shows the typical pattern of west to east migration probably involving long-distance dispersal (Stull et al. 2017).

In working on the Pacific material, we realised that there are undescribed species present. So our first aim was to produce a list of species present in the region incorporating the recent nomenclatural changes. We have included the description of four new species, three from the region and one from New Guinea.

\section{Material and methods}

The study was based on the relevant literature (Guillaumin 1948; Whitmore 1966; Foreman 1972; Smith 1981; Hancock \& Henderson 1988) on the flora of the region and recent revisionary works (cited below) plus specimens in the herbarium of the Royal Botanic Gardens Kew (K). We focussed on genera that extend out into the Pacific beyond New Guinea and its near neighbours. In other words, those that reach at least the Solomon Archipelago (Solomon Islands plus Bougainville which is politically part of Papua New Guinea). As only a few extra species are involved, we also include the species from Micronesia. Cananga (Dunal) Hook.f. \& Thomson was excluded from the analysis, as the only representative, Cananga odorata (Lam.) Hook.f. \& Thomson, has a history of cultivation in the region and has probably been spread by human introduction (Florence 2004). Annona L. was also omitted for the same reasons.

For conservation assessments, the IUCN (2012) criteria were followed. The Extent of Occurrence (EOO) and Area of Occupancy (AOO) were calculated using the Geocat software (http://geocat.kew. org; see Bachman et al. 2011). The EOO was estimated as the surface of the smallest convex polygon encompassing all locations but where large areas of unsuitable habitat occur (especially germane to island groups), then EOO was estimated by using an online Google Maps Area Calculator (https://www. daftlogic.com/projects-google-maps-area-calculator-tool.htm). The AOO was calculated as the sum of the surfaces of $2 \mathrm{~km} \times 2$ cells in which the species occurred (e.g., $4 \mathrm{~km}^{2} \times$ number of cells occupied by the species). A 2-km grid size was used in order to be able to apply the thresholds defined by the IUCN, as recognised in the guidelines.

\section{Results}

Based on our survey of herbarium specimens and the literature, excluding Cananga, nine genera (Drepananthus, Goniothalamus, Huberantha, Meiogyne, Monoon, Polyalthia s. str., Popowia, Uvaria, and Xylopia) as currently recognised and represented by at least 40 species, are found in the Western Pacific beyond New Guinea. Of these, the occurrence of Monoon in the Solomon Archipelago seems not to have been previously reported. We describe two new species of Monoon and two new species of Huberantha.

\section{Monoon in Melanesia}

The generic name Monoon was recently taken up again (Xue et al. 2012) for a group of 60-70 species, mostly formerly included in Polyalthia, Enicosanthum, Cleistopetalum and Woodiellantha. The genus has not been monographed, but in listing the species that they recognised in the genus and making many new combinations, Xue et al. (2012) included three species from New Guinea: Monoon chloranthum (Lauterb. \& K.Schum.) B.Xue \& R.M.K.Saunders, Monoon chloroxanthum Miq. and Monoon polycarpum (Burck) B.Xue \& R.M.K.Saunders. In going through the material of Monoon from New Guinea and the Solomons, it became obvious to us that more species were present than these three. One group of specimens with very thick, fleshy petals clearly differed from the described taxa which all have relatively thin petals. The fleshy-flowered group included a New Guinea gathering distributed as Polyalthia pachypetala Diels. However, this name appears never to have been published. The thick- 
petaled specimens from the Solomons differ significantly from the New Guinea material, so we describe both as new. There is possibly a third species with fleshy petals represented by a specimen from New Britain (NGF 22441), but the material is too limited to describe.

We consider these species to belong in Monoon due to the possession of eucamptodromous leaf venation, decurrent insertion of lateral nerves to the midrib, uniovulate carpels and (where available) relatively soft seeds with an irregular longitudinal groove and lamelliform endosperm quartering the seed in transverse section.

\author{
Class Magnoliopsida Brongn. \\ Order Magnoliales Juss. ex Bercht. \& J.Pres1 \\ Family Annonaceae Juss. \\ Monoon Miq. \\ Monoon pachypetalum I.M.Turner \& Utteridge sp. nov. \\ urn:lsid:ipni.org:names:77164167-1 \\ Figs 1-2
}

\title{
Diagnosis
}

Differs from the other described species of Monoon from Melanesia in its relatively short and thick flower pedicels and broadly ovate, thick fleshy petals. Differs from Monoon salomonicum sp. nov. in having a distinctly asymmetric leaf base and subsessile monocarps.

\section{Etymology}

We maintain the epithet chosen by Diels which reflects the thick petals of the new species.

\section{Type}

INDONESIA: Papua, Nordküste, Mittellauf des Tor-Flusses, 11 Oct. 1911, K. Gjellerup 738 (holo-: B10 0365021; iso-: K000691685).

\section{Additional specimens examined}

INDONESIA: Papua, SE West Irian, Mindip Tanah, along Imko River, 3 Jun. 1971, Nedi 781 (K); West Papua, NE Kepala Burung, Kabupaten Manokwari, Nuni, Sungai Asia, 15 Aug. 1995, J. Dransfield $J D 7565$ (K [2 specs]).

\section{Description}

Tree to at least $10 \mathrm{~m}$ tall, $10 \mathrm{~cm}$ dbh. Twigs drying blackish or dark brown, longitudinally wrinkled, sometimes with small brown, round or oval lenticels; youngest parts with pale brown tomentum, otherwise glabrous. Leaves chartaceous, drying grey-brown above, brown or grey-brown below with darker brown midrib and lateral nerves, midrib slightly sunken above in dry leaves, prominent below, lateral nerves more or less flush above, raised below, glabrous or sparsely hairy along midrib above, glabrous or with scattered hairs on nerves below, lamina ovate-elliptic to obovate, $7-21 \times 2.5-8 \mathrm{~cm}$, apex shortly acuminate, base obtuse to cordate, distinctly asymmetric with one side more markedly lobed, lateral nerves 9-12 pairs, arching forward and running more or less parallel before looping obscurely just within margin, intersection of laterals with midrib decurrent, tertiary venation scalariform, distinct from both surfaces in dry leaves; petioles 4-6 $\mathrm{mm}$ long, drying blackish, minutely wrinkled, sometimes with brown hairs. Inflorescences axillary, solitary, single-flowered. Flowering pedicel 7-15 mm long, 1-1.5 mm diameter, widening distally, drying dark brown, wrinkled, sparsely hairy; medial bract broadly ovate ca $1 \times 2 \mathrm{~mm}$, hairy outside, glabrous within; calyx connate forming 3-pointed cup, each 


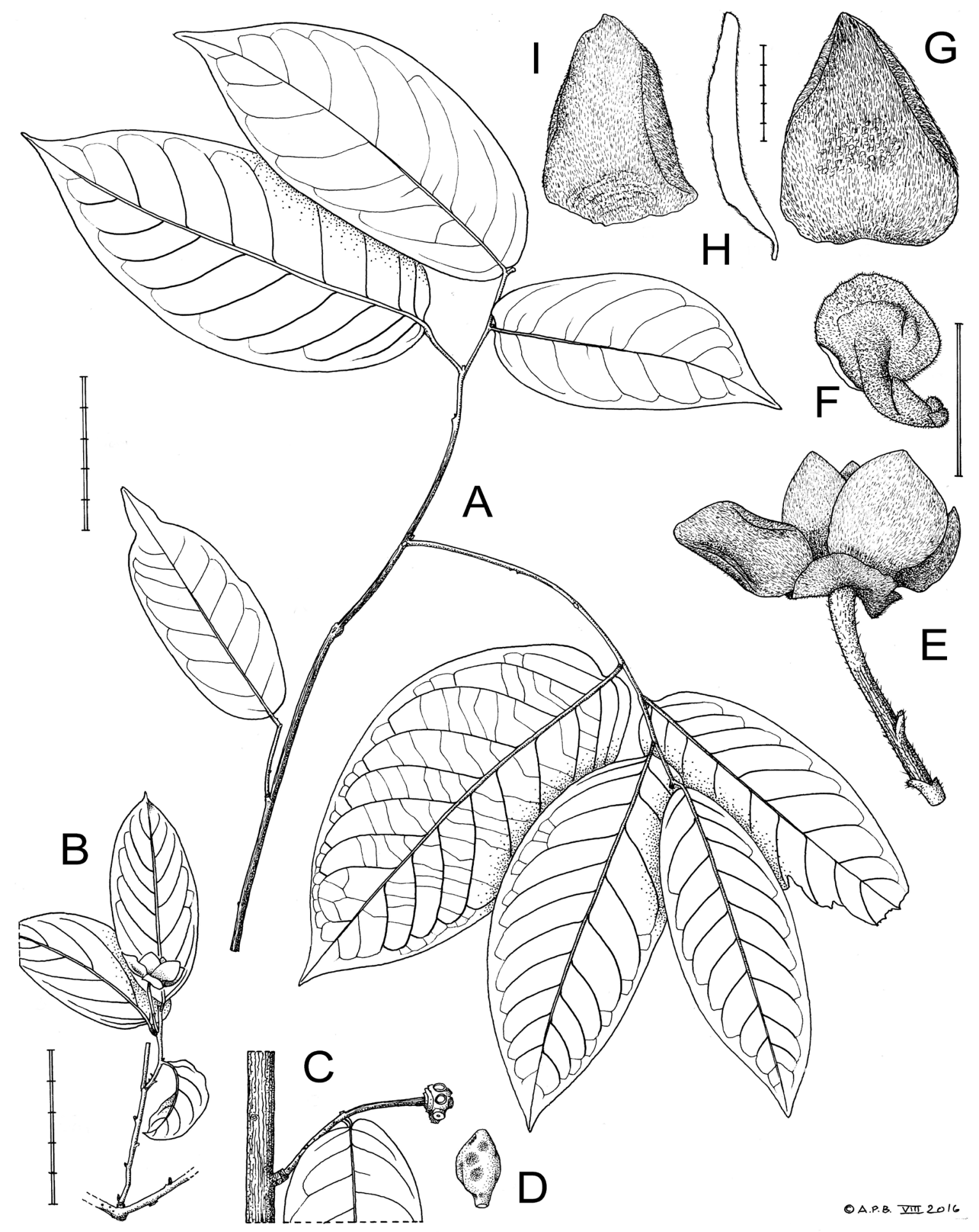

Fig. 1. Monoon pachypetalum I.M.Turner \& Utteridge sp. nov. A. Foliage. B. Shoot bearing flower in leaf axil. C. Shoot bearing old fruit without monocarps. D. Detached monocarp. E. Flower, lateral view. F. Flower pedicel and calyx viewed from below. G. Outer petal, abaxial view. H. Median longitudinal section through outer petal. I. Inner petal, abaxial view. Scale bars: graduated single bar $=5 \mathrm{~mm}$; double bar $=1 \mathrm{~cm}$; graduated double bar $=5 \mathrm{~cm}$. Drawn from Dransfield JD7565 (A, C, D); Nedi 781 (B, E); Gjellerup 738 (F-I). Drawn by Andrew Brown. 
sepal broadly ovate $2 \times 4-5 \mathrm{~mm}$, sparsely short brown hairy outside, glabrous, drying blackish, within; outer petals broadly ovate ca $13 \times 10 \mathrm{~mm}$, base truncate, apex acute, drying ca $1 \mathrm{~mm}$ thick in upper portion, externally verruculose but obscured by dense brown or pale adpressed tomentum, similar inside except for glabrous region near base; inner petals ovate-lanceolate ca $10 \times 7 \mathrm{~mm}$, brown tomentose except for basal part of adaxial surface which dries black, sometimes longitudinally grooved distally and warty proximally, otherwise smooth; stamens many in 4-5 rows, ca $1 \mathrm{~mm}$ long, connective apex polygonal; carpels many. Fruiting pedicel to $25 \mathrm{~mm}$ long, $2 \mathrm{~mm}$ thick, widening distally, drying brown, longitudinally striate, very short pale hairs, monocarps ca 10, drying dull dark brown with very short brown tomentum, ellipsoidal ca $2.5 \times 1.5 \mathrm{~mm}$, subsessile. Seeds 1 .

\section{Field notes}

Bark dark grey, smooth (J. Dransfield JD7565); twigs blackish (J. Dransfield JD7565); leaves mid green (J. Dransfield JD7565); flowers yellow (Nedi 781); fruit pale yellowish green (J. Dransfield JD7565).

\section{Distribution and habitat}

Lowland forest in New Guinea (Fig. 2).

\section{Conservation status}

Currently known from only three collection sites in Indonesian New Guinea: one on the south of the central range just to the north of Tanah Merah, one on the north coast near Sarmi and the other in the Vogelkop coastal area near Manokwari. All three sites appear to be relatively undisturbed when using Google Earth imagery, or close to undisturbed areas, and it is to be expected that Monoon pachypetalum sp. nov. is found in lowland forest throughout Indonesian New Guinea. Using the known collection data, it is difficult to accurately estimate the EOO using GeoCat because of large areas of unsuitable habitat (the high elevations of the central range and the Cendrawasih Bay). An approximate EOO is $55,400 \mathrm{~km}^{2}$ (based on two polygons of $49,000+6,400 \mathrm{~km}^{2}$ excluding unsuitable habitat and encompassing the collection sites) which is outside any of the IUCN threat criteria. However, the AOO is $12 \mathrm{~km}^{2}$ which falls within the EN category and the species is also known from only three locations. However, because

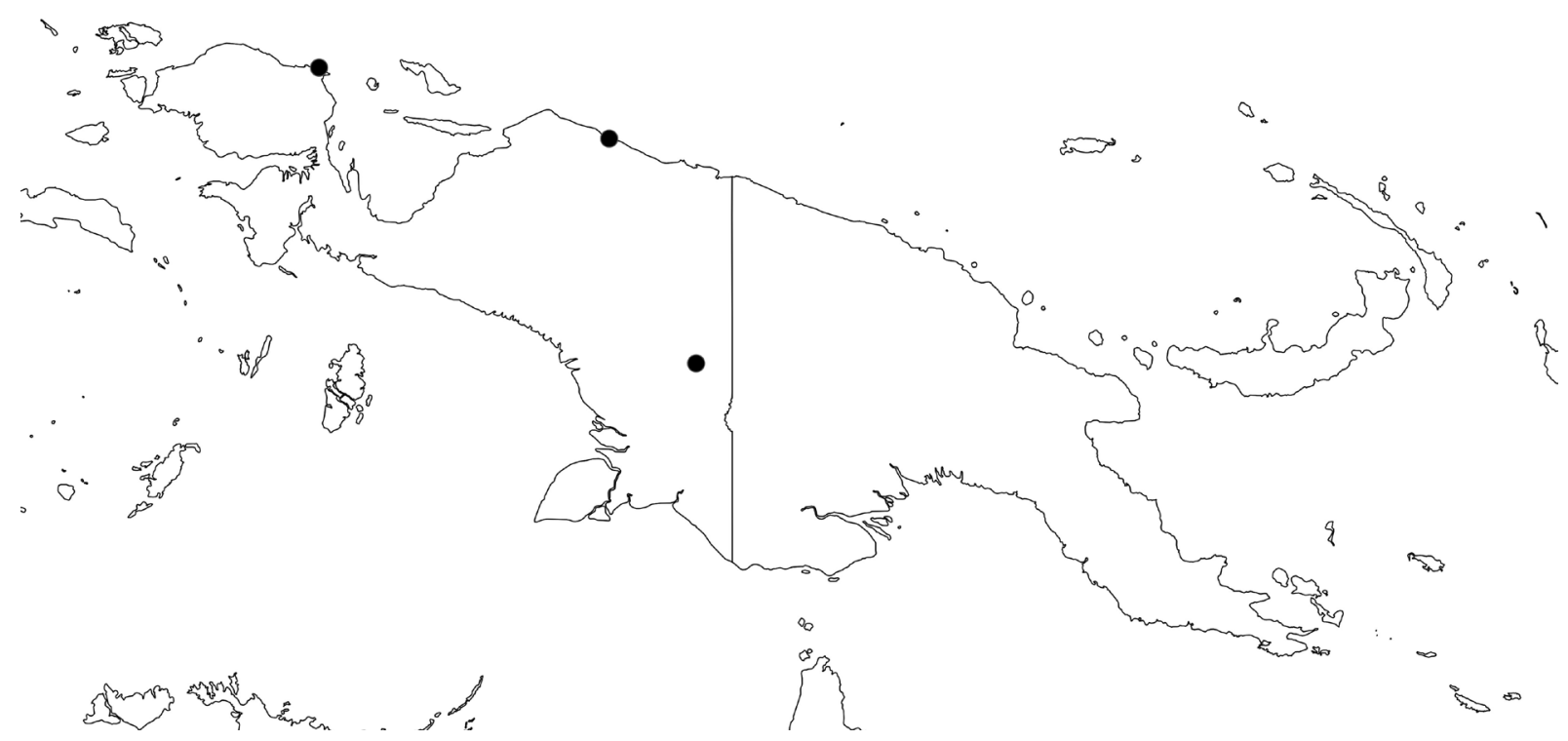

Fig. 2. Map of New Guinea showing the collecting localities of Monoon pachypetalum I.M.Turner \& Utteridge sp. nov. 
the habitat in the environs of the collection localities appears to be intact, we are currently unable to know if the quality of the habitat is declining, etc., and thus the species does not fulfil the two criteria for a geographic range assessment. We thus estimate Monoon pachypetalum sp. nov. as Near Threatened (NT) noting that further collection locations are needed, as well as better observations of population size and habitat quality.

Monoon salomonicum I.M.Turner \& Utteridge sp. nov. urn:Isid:ipni.org:names:77164166-1

Figs $3-4$

\section{Diagnosis}

Differs from the other described species of Monoon from Melanesia in its relatively short and thick flower pedicels and broadly ovate, thick fleshy petals. Differs from M. pachypetalum sp. nov. in having a symmetrical leaf base and stipitate monocarps.

\section{Etymology}

The epithet alludes to the Solomon Archipelago to which the new species is endemic.

\section{Type}

SOLOMON ISLANDS: Santa Ysabel, Allardyce Harbour south side, $7^{\circ} 46^{\prime} 48^{\prime \prime}$ S, $158^{\circ} 38^{\prime} 46^{\prime \prime}$ E, primary forest by river in valley bottom, 24 Jan. 1964, Whitmore's Collectors BSIP 3661 (holo-: K).

\section{Additional specimens examined}

PAPUA NEW GUINEA: Bougainville, Kapikavi, 6²7'39" S, 155³9'14" E, alt. 2500 ft, 3 Feb. 1967, P. Lavarack \& C. Ridsdale NGF 31349 (K).

SOLOMON ISLANDS: Choiseul, north-east Choiseul, Ologhata [Ologholata] Harbour, $7^{\circ} 18^{\prime} 45^{\prime \prime}$ S, 157²4'13" E, Hillside 350 feet, 31 Oct. 1969, I. Gafui et al. BSIP 17419 (K); Kolombangara, 758'34" S, $157^{\circ} 04^{\prime} 18^{\prime \prime}$ E, river valley west of camp site, 4 Sep. 1965, Iromea R.S.S. 2530 (K).

\section{Description}

Tree ca 9-12 $\mathrm{m}$ tall, to $20 \mathrm{~cm}$ dbh. Twigs drying dark brown, longitudinally wrinkled or lozenged, youngest parts with short brown adpressed tomentum, lost with age, sometimes with circular or ellipsoidal paler brown lenticels, flush or slightly raised. Innovations densely adpressed pale brown hairy. Leaves chartaceous, drying grey above, grey-brown below, midrib and lateral nerves flush above, raised below, adpressed brown hairs on midrib above and midrib and lateral nerves below, sometimes sparse; lamina ovate to ovate-lanceolate, $12-28 \times 5-10 \mathrm{~cm}$, apex acute or more commonly acuminate, base cuneate or less commonly truncate, lateral veins 10-11 pairs, visible from both surfaces, arching forward at ca $30-45^{\circ}$ to the midrib, junction between laterals and midrib distinctly decurrent, in one specimen (R.S.S. 2530) including domatia with dense tufts of relatively long, erect pale brown hairs, tertiary venation sclariform to subscalariform, only visible from below; petioles drying blackish or dark brown, horizontally wrinkled, 6-10 $\mathrm{mm}$ long, 2-3 mm wide, often adpressed brown or pale hairy, lamina ultimately slightly decurrent running into two parallel ridges along margins of shallow channel on adaxial side of petiole. Inflorescences axillary, mostly to fallen leaves, peduncle inconspicuous, ca $2-3 \mathrm{~mm}$ long, 2-2.5 mm wide, adpressed brown hairy, longitudinally wrinkled, apparently only bearing 1-2 flowers at any one time. Flowering pedicel ca $8 \mathrm{~mm}$ long, $2 \mathrm{~mm}$ thick, adpressed brown hairy, longitudinally wrinkled; sepals 3 , slightly connate at base, broadly ovate, ca $4 \times 6 \mathrm{~mm}$, apex obtuse, base truncate, thickly coriaceous, adpressed brown hairy outside, glabrous within; petals thickly fleshy, more than $1 \mathrm{~mm}$ thick when dry, broadly ovate, apex obtuse, outer petals ca $10 \times 8 \mathrm{~mm}$, verruculose outside but 


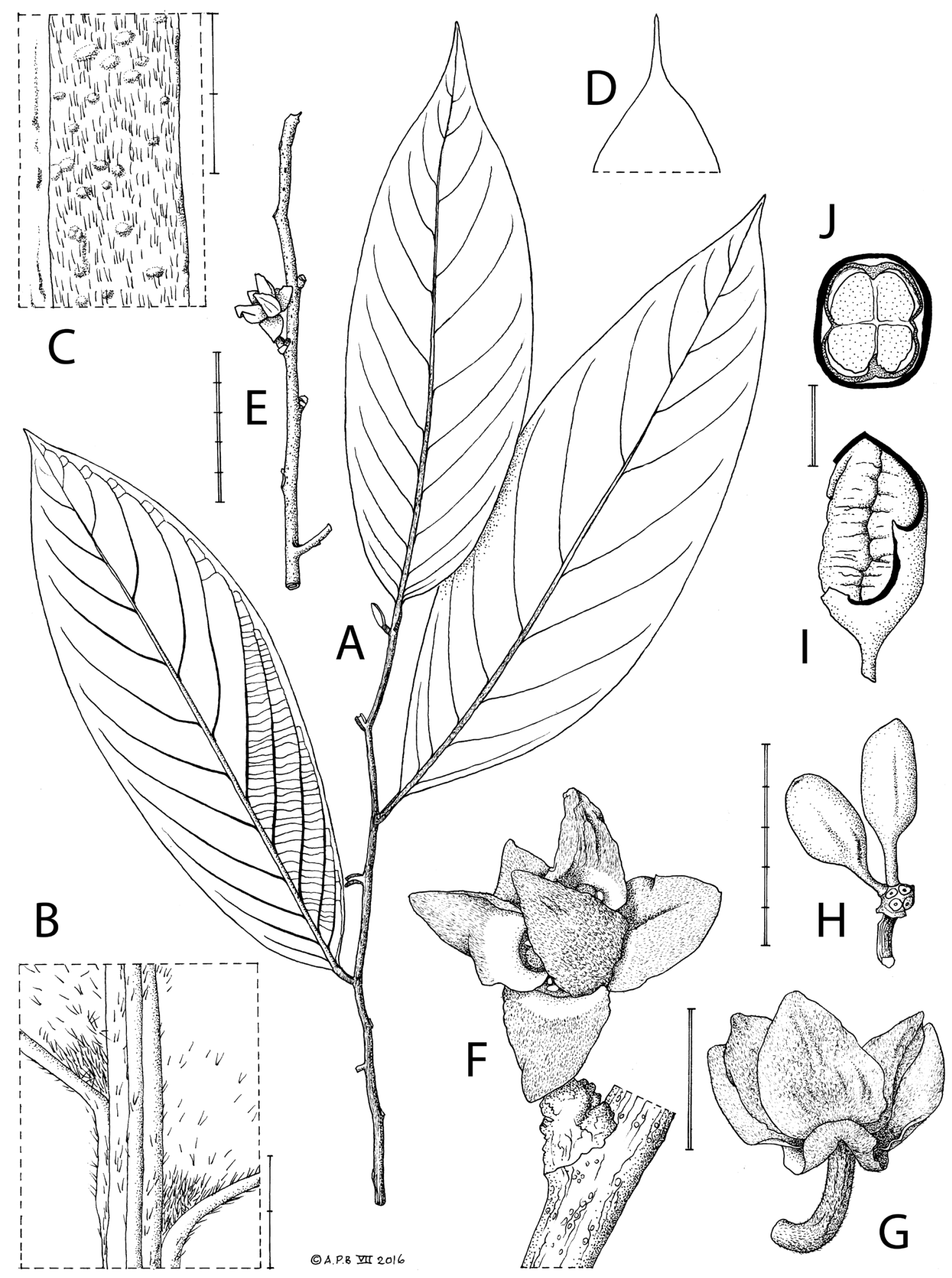

Fig. 3. Monoon salomonicum I.M. Turner \& Utteridge sp. nov. A. Leafy twig. B. Domatia in axils of secondary nerves on leaf abaxial surface. C. Indumentum on adaxial surface of midrib. D. Example of more distinctly acuminate leaf apex. E. Branchlet bearing flower. F, G. Two views of flower, one attached, one detached. H. Fruiting pedicel bearing two monocarps. I. Monocarp with part of pericarp removed to expose seed. J. Transverse section of monocarp. Scale bars: graduated single bar $=2 \mathrm{~mm}$; double bar = $1 \mathrm{~cm}$; graduated double bar $=5 \mathrm{~cm}$. Drawn from BSIP 3661 (A, C, E-J); RSS 2530 (B, D). Drawn by Andrew Brown. 
obscured by dense brown tomentum, inside with very short brown hairs on distal half, but glabrous proximally, drying black and wrinkled, inner petals ca $10 \times 6 \mathrm{~mm}$, similar to outer petals abaxially, inside with longer brown hairs near apex, otherwise glabrous, drying black or dark brown below with longitudinal grooves and warty surface near based; stamens many, ca $1 \mathrm{~mm}$ long, connective apex truncate, polygonal; carpels many, ca $1 \mathrm{~mm}$ long, pale brown hairy, stigma ca $1.5 \mathrm{~mm}$ long, apex acute, glabrous, pale hairy basally. Fruiting pedicel to $18 \mathrm{~mm}$ long, ca 3-4 mm thick, longitudinally striate, densely adpressed brown hairy, monocarps to ca 8 , ellipsoidal, $2.5-3 \mathrm{~cm}$ long, ca $1.5 \mathrm{~cm}$ diameter, thin walled, drying dull black or dark brown, apiculate, verruculose, adpressed brown hairy most noticeably near apex and base, stipes 6-17 mm long, ca $2 \mathrm{~mm}$ thick. Seeds 1, ellipsoidal, ca $2.5 \times 1.5 \mathrm{~cm}$, pale brown with irregular circumferential groove.

\section{Field notes}

Bole crooked (BSIP 3661); bole: straight, buttresses: absent (BSIP 17419); bark surface grey, smooth (BSIP 3661); bark surface: dark brown, smooth (BSIP 17419); slash: wood and bark soft, white (BSIP 3661); slash, wood: soft, brownish white; slash, bark soft (BSIP 17419); flowers yellow, unscented (BSIP 3661); flowers greenish yellow (NGF 31349); fruits yellow (BSIP 3661); fruits: yellowish brown (ripe) (BSIP 17419); fruit orange (NGF 31349); fruits green (R.S.S. 2530).

\section{Distribution and habitat}

Papua New Guinea (Bougainville) and the Solomon Islands (Fig. 4) in lowland to montane forest.

\section{Conservation status}

The species is known from four collections from four locations and is distributed throughout Bougainville and the northern part of the Solomon Islands. The EOO (excluding unsuitable habitat) can be estimated from the areas of Bougainville $\left(9,318 \mathrm{~km}^{2}\right)$, Choiseul $\left(3,837 \mathrm{~km}^{2}\right)$, Kolombangara $\left(680 \mathrm{~km}^{2}\right)$ and northern Santa Isabel island $\left(1,000 \mathrm{~km}^{2}\right)$, totalling $14,835 \mathrm{~km}^{2}$ below the threshold for Vulnerable, and the AOO is only $16 \mathrm{~km}^{2}$ within the Endangered criteria. Because of the very few localities and the continued forest

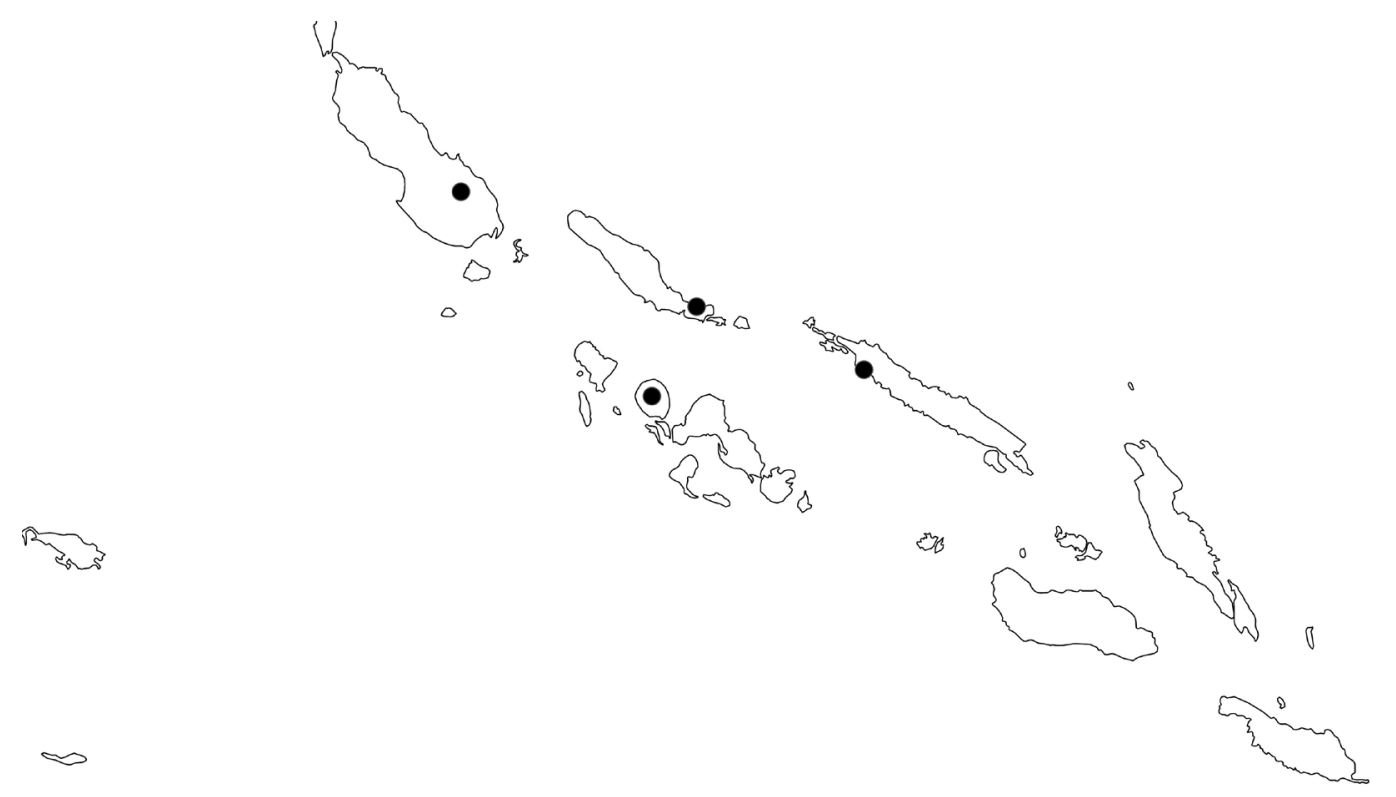

Fig. 4. Map of the Solomon Archipelago showing the collecting localities of Monoon salomonicum I.M.Turner \& Utteridge sp. nov. 
exploitation in the Solomon Islands, we give this species a provisional conservation rating of EN B2 ab(iii, iv).

\section{Notes}

There are at least two more species of Monoon from the Solomon Archipelago but the material available to us (BSIP 15202, BSIP 13474, Craven 537) is too limited to describe.

\section{Huberantha in the Pacific}

Huberantha was only recently recognised as an independent genus; excised from the amorphous Old World Polyalthia s. lat. After a false start with the name Hubera (Chaowasku et al. 2012), some 27 species ranging from East Africa and Madagascar to the South Pacific were transferred to Huberantha (Chaowasku et al. 2015), to be followed by one more from India (Muralidharan et al. 2015) and 4 from Vietnam, the Philippines and New Guinea (Turner 2016). However, the taxonomy of genus is poorly known, particularly in New Guinea and the Pacific. Herbarium material from the Pacific islands included at least 2 new species of Huberantha, which are described below.

We consider these species to belong in Huberantha because they have uniovulate carpels, brochidodromous venation with non-decurrent insertion of lateral nerves to the midrib and more or less cuneate, rather than subcordate leaf bases, and relatively hard seeds.

\section{Huberantha Chaowasku}

Huberantha asymmetrica I.M.Turner \& Utteridge sp. nov. urn:1sid:ipni.org:names:77164168-1

Figs 5-6

\section{Diagnosis}

There are three species of Huberantha in Papuasia and the Pacific that exhibit similar tomentose twigs to the material from the Solomons. The poorly known Huberantha hirta (Miq.) Chaowasku and Huberantha trichoneura (Diels) Chaowasku from New Guinea differ in leaf shape (Huberantha hirta: symmetrical, oblong-ovate; Huberantha trichoneura: symmetrical, oblanceolate with an acute base vs asymmetrical, typically lanceolate with base rounded to obtuse in Huberantha asymmetrica sp. nov.) and in having more or less globose fruits vs conical to ellipsoidal in Huberantha asymmetrica sp. nov. Huberantha loriformis (Gillespie) Chaowasku from Fiji, is distinctly hairier than Huberantha asymmetrica sp. nov. with dense tomentum on the lower lamina and often hairs on the upper lamina giving a soft furry feel below and a scabrid one above. The hairs on the flower pedicels and calyx are longer and denser, and the petals are more distinctly lanceolate with long acute apex in Huberantha loriformis compared to Huberantha asymmetrica sp. nov. The stipes of the monocarps in Huberantha loriformis are shorter (3-5 $\mathrm{mm}$ vs 5-15 $\mathrm{mm}$ ) but thicker ( $2 \mathrm{~mm}$ vs $1 \mathrm{~mm}$ ).

\section{Etymology}

The chosen epithet reflects the asymmetical leaves.

\section{Type}

SOLOMON ISLANDS: San Cristobal, South West San Cristobal, Onebia, ridge top, 200' a.s.1., 21 Nov. 1968, P. Runikera et al. BSIP 12719 (holo-: K). 


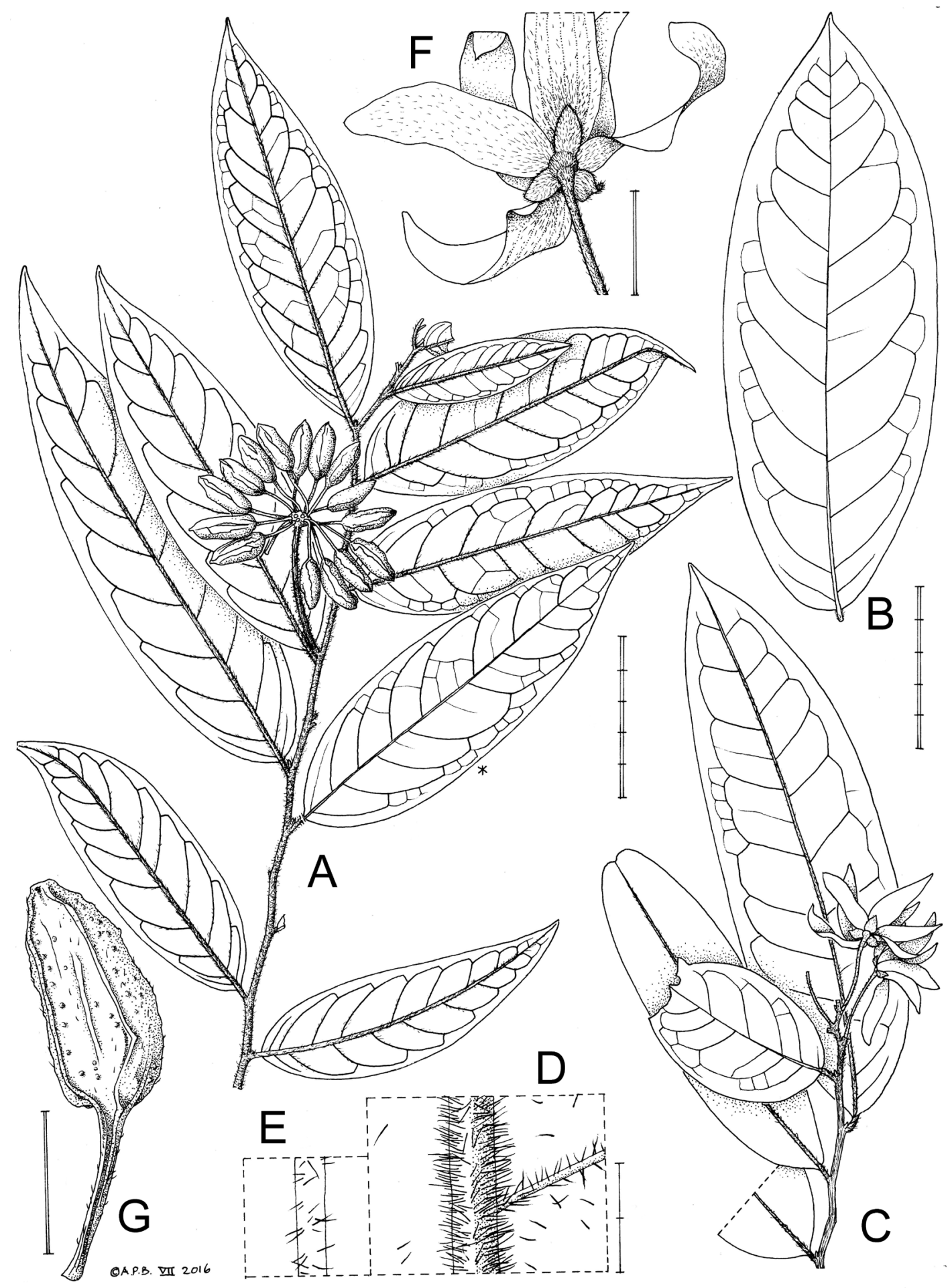

Fig. 5. Huberantha asymmetrica I.M.Turner \& Utteridge sp. nov. A. Leafy shoot bearing fruit (leaf marked with an asterisk showing adaxial surface, rest with abaxial view). B. Leaf (adaxial view) showing distinct asymmetry. C. Flowering shoot. D. Leaf lamina abaxial midrib region showing indumentum. E. Leaf lamina adaxial midrib region showing indumentum. F. Flower viewed from below. G. Monocarp sectioned longitudinally. Scale bars: graduated single bar $=2 \mathrm{~mm}$; double bar $=1 \mathrm{~cm}$; graduated double bar $=5 \mathrm{~cm}$. Drawn from BSIP 12085 (A in part, D, E); BSIP 9859 (A in part, G); BSIP 12719 (C); BSIP 12261 (B). Drawn by Andrew Brown. 


\section{Additional specimens examined}

SOLOMON ISLANDS: Kolombangara Island, north of Bamberi River, ridge top 50' a.s.1., 21 Dec. 1967, I.H. Gafui et al. BSIP 8580 (K); New Georgia, N.W. New Georgia, 8¹5' S, $157^{\circ} 15^{\prime}$ E, Kibukibu River, hillside 120' a.s.1., 5 Nov. 1964, Cowmeadow's collectors BSIP 4811 (K); Santa Ysabel, South Santa Ysabel, Jejova [Jejovo] R., 88'39" S, 159³5'35" E, ridge top, 19 Jul. 1966, Beer's collectors BSIP 7392 (K); Gaudalcanal, East Guadalcanal, Marau, Makina River Area, flat plain 110' a.s.l., 13 May 1968, J. Boraule et al. BSIP 9410 (K); East Guadalcanal, hillside 140' a.s.l., 26 Sep. 1968, R. Mauriasi et al. BSIP 11821 (K); North East Guadalcanal, Rere River, ca 3 miles inland, forest on low ridge, 28 Nov. 1963, T.C. Whitmore BSIP 3842 (K); SE Guadalcanal, near Vulemba Village (Avu Avu), ridge top 850' a.s.l., 27 May 1968, B. Sirute'e et al. BSIP 9859 (K); South West Guadalcanal, Wanderer Bay Area, riverside 60' a.s.1., 22 Oct. 1968, R. Mauriasi et al. BSIP 12261 (K); South West Guadalcanal, Duidui Area, ridge top 2,000' a.s.1., 9 Oct. 1968, R. Mauriasi et al. BSIP 12085 (K).

\section{Description}

Tree to $12 \mathrm{~m}$ tall, $30 \mathrm{~cm}$ dbh. Twigs variably tomentose, from densely and persistently red-brown or pale brown hairy, at least on youngest parts, to sparsely so; otherwise drying brown, longitudinally striate, often with impressed lozenges. Leaves chartaceous, drying brown or grey-brown generally with midrib below appearing a darker brown, midrib flush to slightly sunken above, prominent below, lateral nerves flush to very slightly raised above, raised below; hairs, sometimes dense, on nerves and midrib below and along midrib above, sometimes scattered on lower lamina surface; lamina oblong-ovate or oblongobovate to more typically elliptic-lanceolate to lanceolate, $3.5-19 \times 1.7-7 \mathrm{~cm}$, usually asymmetric with one half slightly larger, most obvious as a lopsided base to the leaf, apex acute to more frequently acuminate, base obtuse to rounded, lateral nerves 8-14 pairs, looping distinctly well within margin, tertiary venation reticulate, distinct on both surfaces in dry leaves; petioles $3-5 \mathrm{~mm}$ long, $0.5-2 \mathrm{~mm}$ thick, sparsely to densely hairy. Inflorescences axillary, peduncle ca $1 \mathrm{~mm}$ long, densely red-brown hairy, apparently bearing a single flower at a time. Flowering pedicel $22-24 \mathrm{~mm}$ long, ca $1 \mathrm{~mm}$ wide, broadening distally slightly, drying dark brown or black, longitudinally striate, minutely pimpled with sparse red-brown hairs; sepals ovate-lanceolate ca $5 \times 3 \mathrm{~mm}$, drying dark brown or black with scattered

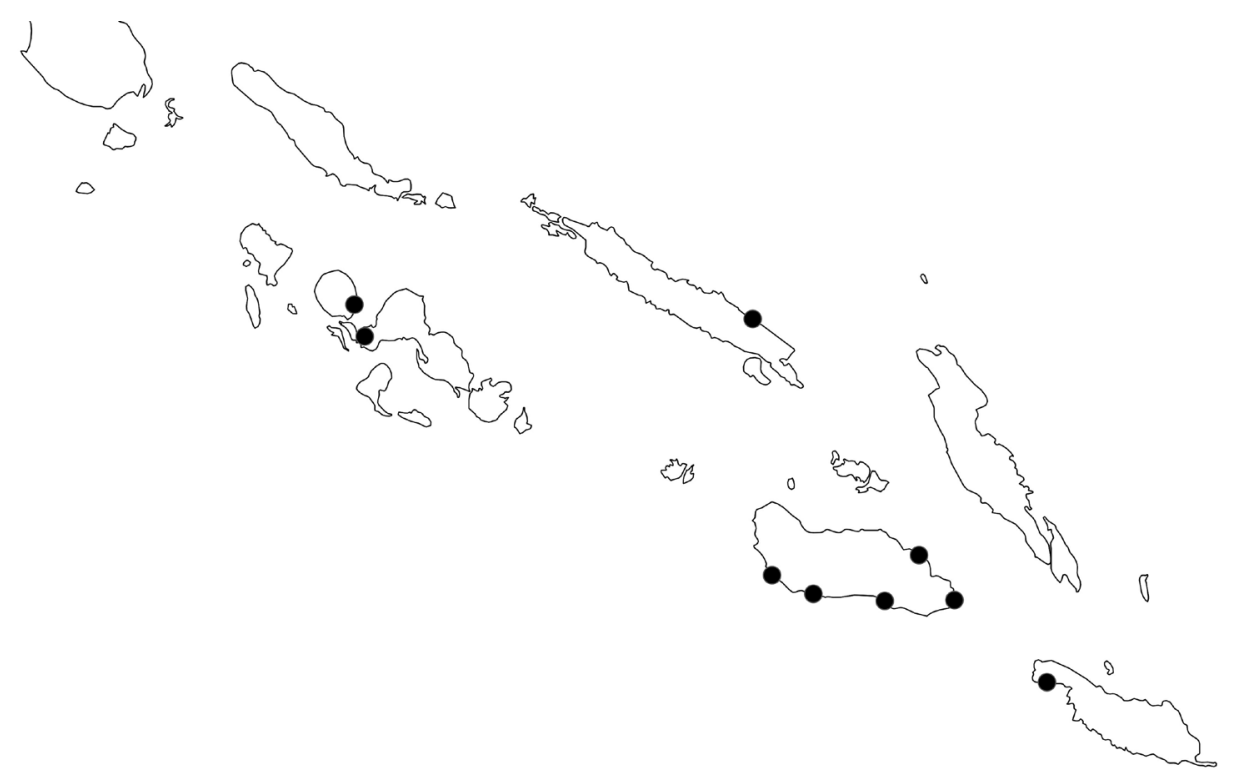

Fig. 6. Map of the Solomon Archipelago showing the collecting localities of Huberantha asymmetrica I.M.Turner \& Utteridge sp. nov. 
red-brown hairs externally, glabrous within, calyx lobes distinctly separated, not touching even at base; petals linear-lanceolate, ca $3 \mathrm{~cm}$ long, drying black or dark brown with scattered pale hairs, inner petals slightly wider ( 9 vs $7 \mathrm{~mm}$ ); stamens many, ca $1 \mathrm{~mm}$ long, drying pale brown, connective apex truncate, very minutely hairy or papillose; carpels many, ca $1 \mathrm{~mm}$ long, densely pale hairy, stigmas ca $1 \mathrm{~mm}$ long. Fruiting pedicel 1.5-4 cm long, 1-2 mm diameter, drying dark brown, striate, with scattered hairs, monocarps few to at least 20 , rather variable in shape from conical to ellipsoidal but generally broadest near base and tapering to an acute apex, 15-18 $\times 5-10 \mathrm{~mm}$, drying black with a few coarse wrinkles and pimples and scattered red-brown hairs, stipe $5-15 \mathrm{~mm}$ long, ca $1 \mathrm{~mm}$ wide, drying longitudinally striate with a scattering of red-brown hairs. Seeds 1.

\section{Field notes}

Bark dark brown (BSIP 4811, BSIP 8580, BSIP 9859, BSIP 11821, BSIP 12085), black (BSIP 12719), smooth (BSIP 4811, BSIP 11821, BSIP 12085, BSIP 12719); flowers yellowish white, smell (BSIP 12719), brownish pink with green centre (BSIP 11821); fruits green (BSIP 9859, BSIP 9410), light green (BSIP 7392), light green, oval, in large bunch (BSIP 12261), green, oval and pointed at the tip (BSIP 11821 ), greenish brown (in large umbel), oval and slightly curve (BSIP 12085), brown, banana shaped, $1 / 2$ " long, 1/8" diameter (BSIP 8580), green, 1/4" elliptical.

\section{Distribution and habitat}

Solomon Islands (Fig. 6) in lowland and hill forest, to $600 \mathrm{~m}$ a.s.1.

\section{Conservation status}

This new species is endemic to the Solomon Islands but is known only from 10 collections from 10 locations, with the last collection made in 1968. The EOO (excluding unsuitable habitat) is $15,600 \mathrm{~km}^{2}$ falls within the Vulnerable criterion, and the AOO of $40 \mathrm{~km}^{2}$ is within the Endangered criterion. Because of the number of collections (10 or less) and the amount of excessive logging in the Solomon Islands (Katovai et al. 2015), we give Huberantha asymmetrica sp. nov. a preliminary conservation assessment of VU B1ab(iii, iv).

\section{Huberantha whistleri I.M.Turner \& Utteridge sp. nov. urn:Isid:ipni.org:names:77164169-1}

Figs $7-8$

\section{Diagnosis}

Similar to Huberantha amoena of Fiji but with broader leaves in absolute $(4-6.5 \mathrm{~cm}$ vs up to $4 \mathrm{~cm})$ and relative terms (length: breadth ratio of less than 3 vs 3-4), less slender flowering pedicel ( $0.75 \mathrm{vs}$ $0.5 \mathrm{~mm}$ diameter), broader stamen connective apex $(1.5 \mathrm{vs} 0.5 \mathrm{~mm})$, and longer stipes to the monocarps $(12-15 \mathrm{vs} 10-11 \mathrm{~mm})$. Huberantha amoena appears habitually to have tiny hairy domatia in the axils of the lateral nerves on the abaxial lamina surface which are absent in the material of Huberantha whistleri sp. nov.

\section{Eponymy}

We are pleased to name this species in honour of W. Arthur ("Art") Whistler, the discoverer of this and many other Pacific taxa.

\section{Type}

SAMOA: Savai'i, growing in the forest above Ologogo; elevation $600 \mathrm{~m}$ a.s.1., 23 Mar. 1973, A. Whistler 576 (holo-: K000607798; iso-: BISH0428621, BISH0711560, K000607799, NTBG). 


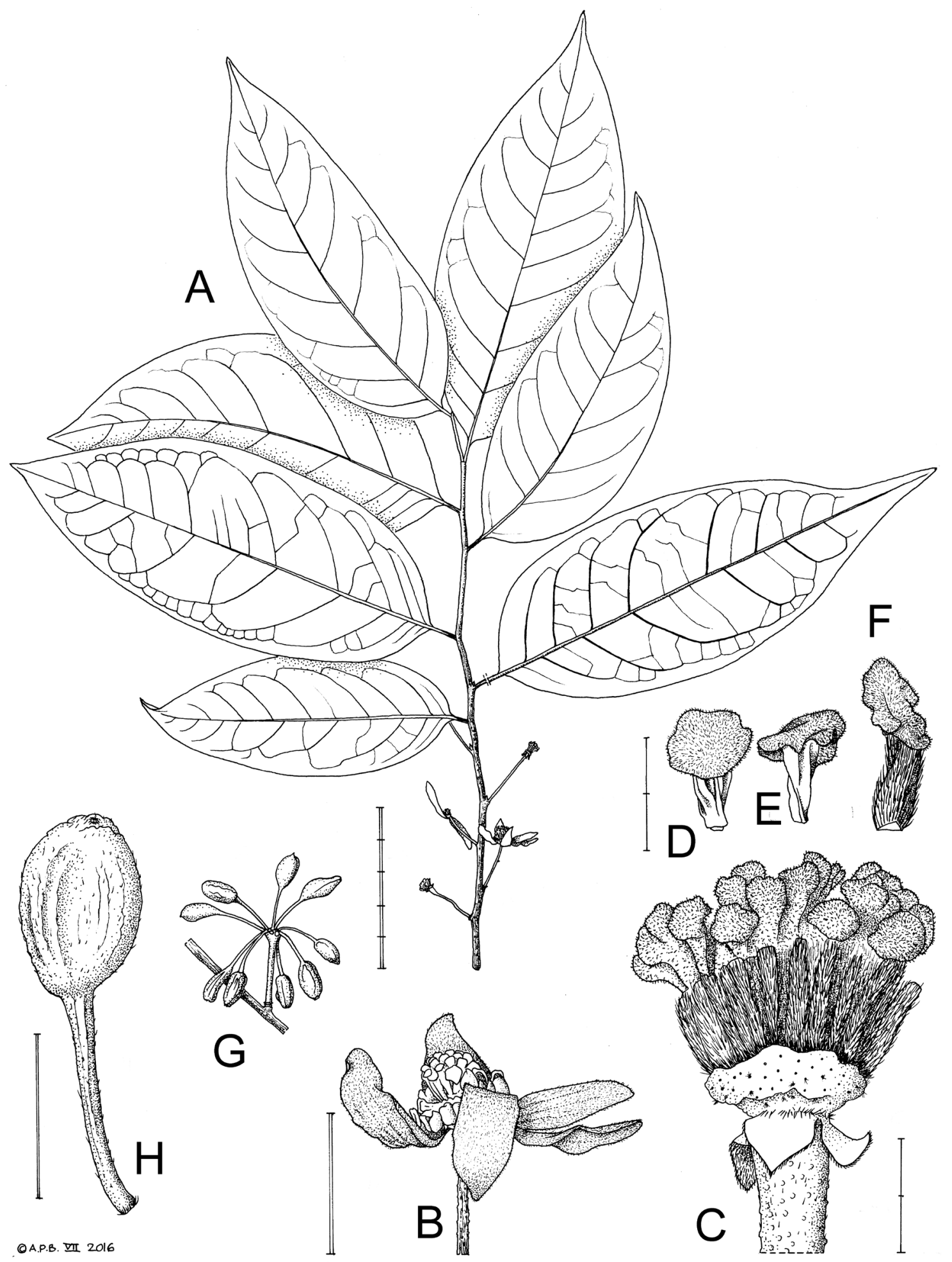

Fig. 7. Huberantha whistleri I.M.Turner \& Utteridge sp. nov. A. Flowering shoot (lower right leaf showing abaxial surface, rest adaxial). B. Flower lateral view (one petal missing). C. Remnant flower with carpels and persistent calyx after loss of corolla and stamens. D, E. Two views of stamen. F. Ovary and stigma. G. Fruit (same scale as A). H. Monocarp (immature). Scale bars: graduated single bar = $2 \mathrm{~mm}$; double bar $=1 \mathrm{~cm}$; graduated double bar $=5 \mathrm{~cm}$. Drawn from Whistler 576 . Drawn by Andrew Brown. 


\section{Description}

Tree $8 \mathrm{~m}$ tall. Twigs drying dark brown or grey-brown, longitudinally striate or with impressed lozenges, glabrous. Leaves membranous to chartaceous, glabrous, drying grey above with midrib pale brown, paler grey below with midrib dark brown, midrib slightly sunken above in dry leaves, prominent below, lateral nerves slightly raised on both surfaces, lamina oblong-ovate to oblong-lanceolate, 11-18 $\times 4-6.5 \mathrm{~cm}$, apex acuminate, base obtuse to rounded, ultimately slightly decurrent to petiole, lateral nerves 9-12 pairs, initially running out at about $70^{\circ}$ to the midrib then arching forward and looping some $1-4 \mathrm{~mm}$ within margin, tertiary venation reticulate and visible from both surfaces in dry leaves; petiole drying blackish or dark brown, 6-9 mm long, 1-1.5 mm thick, minutely wrinkled, glabrous. Inflorescences in axils of fallen leaves bearing 1 or 2 flowers at one time, peduncle $1-2 \mathrm{~mm}$ long with scattered short red-brown hairs. Flowering pedicel $17-20 \mathrm{~mm}$, ca $0.75 \mathrm{~mm}$ thick, widening distally, drying dark brown, longitudinally striate and minutely pimpled; sepals broadly ovate-triangular ca $1 \times 1.5 \mathrm{~mm}$, red-brown hairy outside, glabrous within drying black-brown; petals linear lanceolate to slightly spathulate, 12 $20 \mathrm{~mm}$ long, 4-5 $\mathrm{mm}$ wide, with outer petals wider at base ca $2 \mathrm{~mm}$ vs $1 \mathrm{~mm}$ in inner petals, drying dark brown with short pale brown hairs; stamens many, ca $1.5 \mathrm{~mm}$ long, drying pale brown, connective apex flat, polygonal ca $1.5 \mathrm{~mm}$ diameter, minutely hairy; carpels many, ca $2 \mathrm{~mm}$ long, densely pale brown hairy, stigmas capitate, short hairy. Fruiting pedicel to $23 \mathrm{~mm}$ long, $2 \mathrm{~mm}$ wide, drying dark brown, minutely wrinkled and pimpled, monocarps to 16 or more, (immature) ellipsoidal ca $10 \times 5 \mathrm{~mm}$, drying dark brown to black, with scattered brown hairs, stipes $12-15 \mathrm{~mm}$ long, ca $1 \mathrm{~mm}$ wide.

\section{Distribution and habitat}

Samoa (Fig. 8) in hill forest.

\section{Conservation status}

The species is currently only known from the northern slopes of Savai'i (we have not had access to the second sterile collection Whistler $9481 a$ - above Sāsina in lowland forest at $270 \mathrm{~m}$ a.s.1.). Whistler (2011: 75) has noted that the species is "rare in lowland to foothill forest" in this location, but he gives
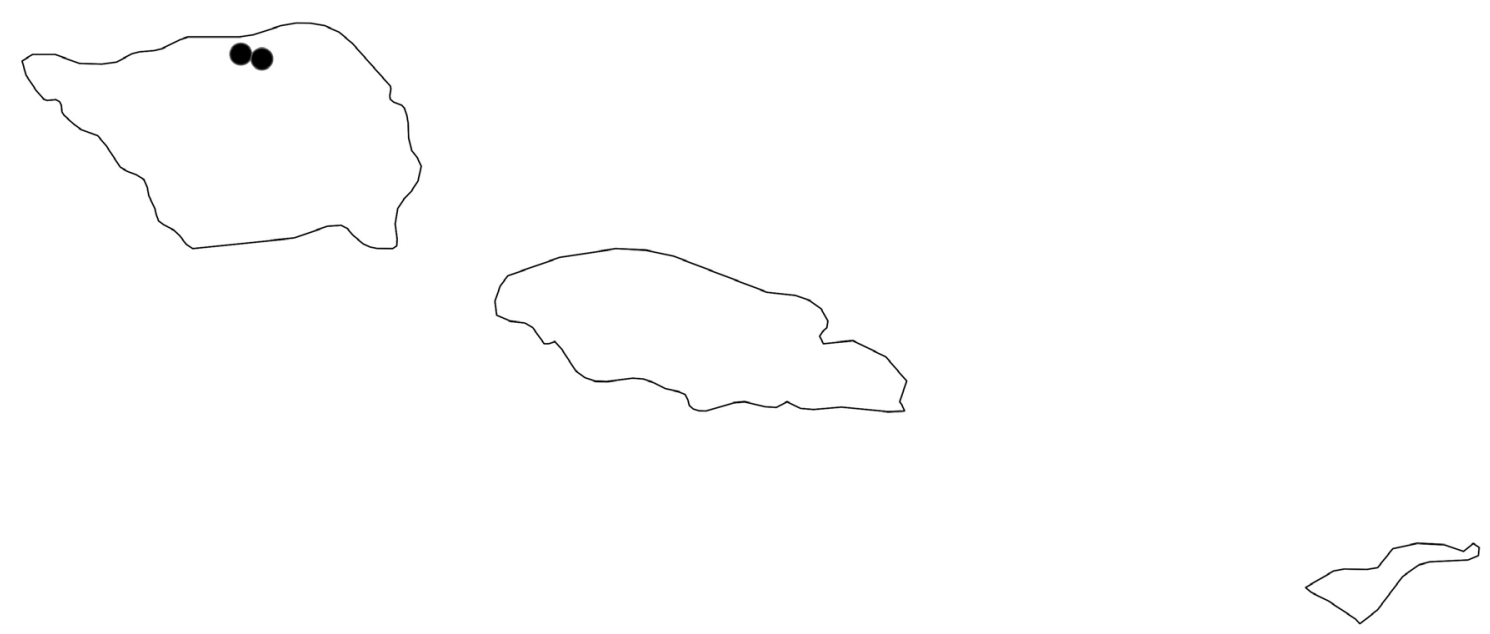

Fig. 8. Map of Samoa showing the collecting localities of Huberantha whistleri I.M.Turner \& Utteridge sp. nov. 
no further information on the habitat or the population size. From Google Earth imagery, the habitat is disturbed in some areas on the north coast around Sasina (but this may be natural disturbance due to typhoons), but also shows some areas with complete tree cover, and with only two points we are unable to calculate an EOO; we therefore we give this species a preliminary conservation rating of Near Threatened (NT).

\section{A list of the Annonaceae species of the Western Pacific}

Species are listed alphabetically within genera. Synonymy and typification are included. The regional distribution (in the Western Pacific) of each taxon is given. For genera, this is summarised as a distribution map. For species, a listing by island or island group is made citing representative collections, if a relevant type specimen is not already cited.

Class Magnoliopsida Brongn.

Order Magnoliales Juss. ex Bercht. \& J.Presl

Family Annonaceae Juss.

Drepananthus Maingay ex Hook.f. \& Thomson

Flora of British India 1: 56 (Hooker \& Thomson 1872). - Lectotype designated by Hutchinson (1923: 258): Drepananthus pruniferus Maingay ex Hook.f. \& Thomson.

\section{Regional distribution}

Fig. 9.

Drepananthus novoguineensis (Baker f.) I.M.Turner \& Utteridge comb. nov. urn:Isid:ipni.org:names:77164170-1

Basionym: Cyathocalyx novoguineensis Baker f., Journal of Botany 61 (Suppl.): 3 (Baker 1923). Type: New Guinea, Sogeri Region, [Mt Gawada], 1885-1886, H.O. Forbes 544 (holo-: BM000546903; iso-: BRI-AQ0210735, FI007547, K, L0037905, SING0026209).

Cyathocalyx obtusifolius var. angustifolius Baker f., Journal of Botany 61 (Suppl.): 3 (Baker 1923). - Type: New Guinea, Sogeri Region, 1885-1886, H.O. Forbes 661 (holo-: BM000608827; iso-: MEL578174).

\section{Regional distribution}

Solomon Archipelago (BSIP 5260, BSIP 16178, BSIP 3642, BSIP 15156).

\section{Notes}

In their paper confirming the phylogenetic separation of Drepananthus from Cyathocalyx, Surveswaran et al. (2010) considered Cyathocalyx novoguineensis as a synonym of Drepananthus petiolatus (Diels) Survesw. \& R.M.K.Saunders. In our opinion these two taxa can be distinguished. The petal blades are generally much shorter in Drepananthus petiolatus (to $1 \mathrm{~cm}$ long compared to at least $6 \mathrm{~cm}$ in Cyathocalyx novoguineensis from New Guinea), more strictly linear rather than long tapering, and glabrescent vs densely pale hairy. Drepananthus petiolatus appears to be a highland species and Cyathocalyx novoguineensis a lowland one, though there may be some overlap in altitudinal ranges. However, there is no indication that the different morphologies are simply an effect of altitude. We therefore make a new combination here for Cyathocalyx novoguineensis in Drepananthus. 
There is a species of Drepananthus widely collected in the Melanesian Solomon Islands. Morphologically the specimens are similar to Drepananthus novoguineensis (Baker f.) I.M.Turner \& Utteridge comb. nov. The specimens seen have shorter petal blades than the New Guinea material (to $2 \mathrm{~cm}$ long vs up to $6 \mathrm{~cm}$ ) and they are less densely hairy, but otherwise flower and fruit forms are congruous. We therefore include this Solomon Islands' material in Drepananthus novoguineensis (Baker f.) I.M.Turner \& Utteridge comb. nov.

Drepananthus vitiensis (A.C.Sm.) Survesw. \& R.M.K.Saunders

Taxon 59 (6): 1731 (Surveswaran et al. 2010). - Cyathocalyx vitiensis A.C.Sm., Bulletin of the Bernice P. Bishop Museum 141: 64, fig. 31 (Smith 1936). - Type: Fiji, Vanua Levu, Mbau Province, in the lower Wainunu River Valley, 7 May 1934, A.C. Smith 1720 (holo-: BISH1000665; iso-: GH, K, NY, P, S, UC, US, WIS).

Cyathocalyx insularis A.C.Sm., Journal of the Arnold Arboretum 31: 161 (Smith 1950). - Type: Fiji, Viti Levu, Mba Province, in hills between Nggaliwana and Tumbeindreketi Creeks, east of the sawmill at Navai, 2 Sep. 1947, A.C. Smith 5868 (holo-: A00039266, A00039267; iso-: BISH1000663, BRI, K, L, NY, P, S, US).

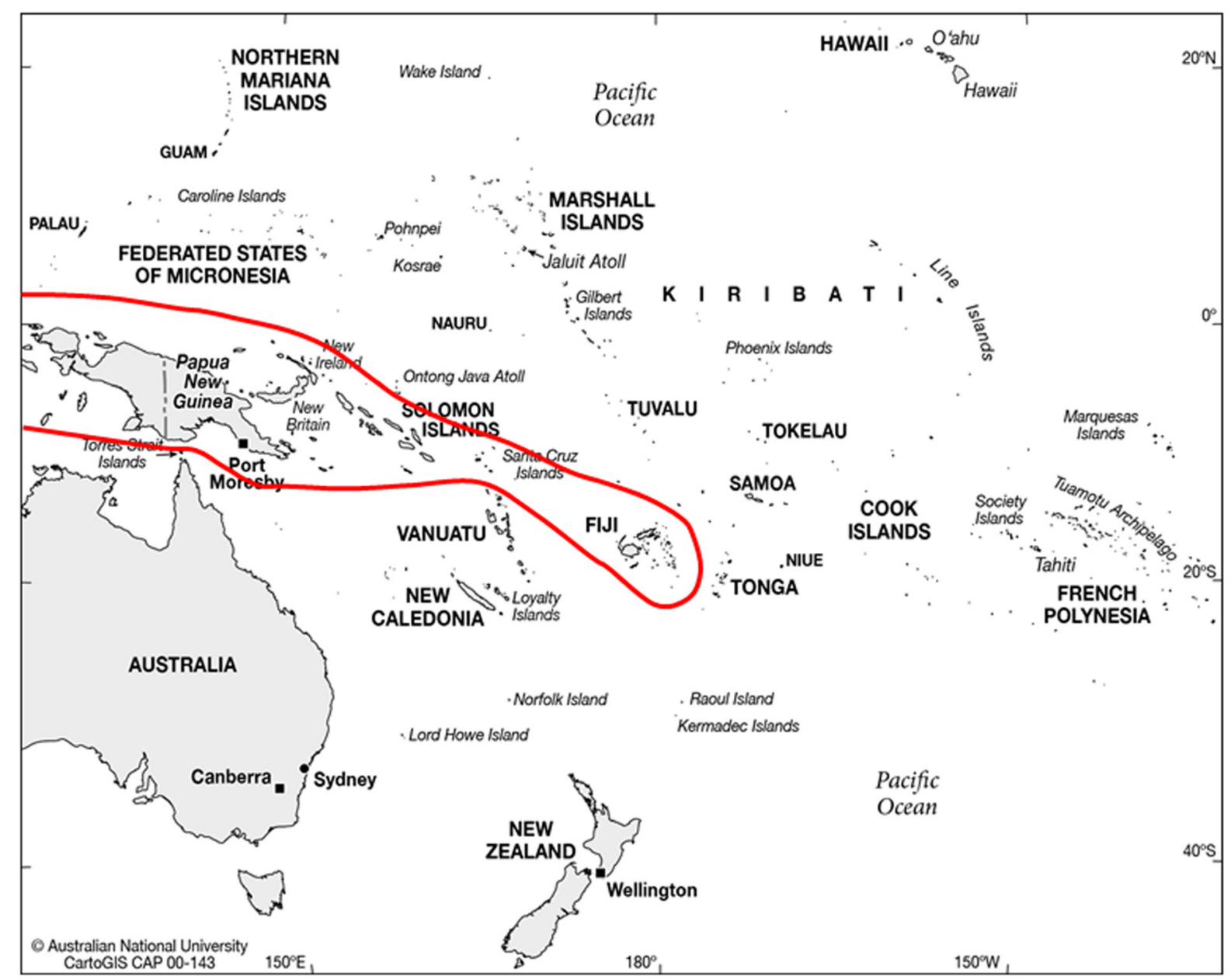

Fig. 9. Regional distribution of the genus Drepananthus (Annonaceae) in the Pacific. Base map sourced from CartoGIS, College of Asia and the Pacific, The Australian National University, Australia. 
Cyathocalyx stenopetalus A.C.Sm., Journal of the Arnold Arboretum 31: 162 (Smith 1950). - Type: Fiji, Viti Levu, in the valley of Nggaliwana Creek, north of the sawmill at Navai, 21 Jul. 1947, A.C. Smith 5342 (holo-: A00039268; iso-: BISH, BRI, K, L, NY, P, S, US).

Cyathocalyx suaveolens A.C.Sm., Journal of the Arnold Arboretum 31: 163 (Smith 1950). - Type: Fiji, Vanua Levu, Mathuata Province, at the southern base of the Mathuata Range, north of Natua, 1 Dec. 1947, A.C. Smith 6778 (holo-: A00039269; iso-: BRI, K, L, NY, P, S, US).

\section{Regional distribution}

Fiji; Santa Cruz islands, Vanikoro (BSIP 7622, BSIP 5260, BSIP 3642).

\section{Notes}

Specimens of Drepananthus collected from Vanikoro Island in the Santa Cruz group have far broader petals than the material from the Melanesian part of the Solomon Islands. Surveswaran et al. (2010) reduced the four species of Cyathocalyx described by Smith from Fiji to Drepananthus vitiensis. The limited amount of material available from Vanikoro seems to fall within the variability exhibited by the Fijian taxon, so we refer the collections to that species.

\section{Goniothalamus Hook.f. \& Thomson}

Flora Indica: 105 (Hooker \& Thomson 1855) nom. cons. - Lectotype designated by Hutchinson (1923: 259): Goniothalamus macrophyllus (Blume) Hook.f. \& Thomson.

Richella A.Gray, Proceedings of the American Academy of Arts and Sciences 2: 324 (Gray 1852) nom. rej. - Type: Richella monosperma A. Gray.

Atrutegia Bedd., Madras Journal of Literature and Science, ser. III, 1: 37, tab. 1 (Beddome 1864). Type: Atrutegia wynadensis Bedd.

Beccariodendron Warb., Botanische Jahrbücher für Systematik, Pflanzengeschichte und Pflanzengeographie 13: 452 (Warburg 1891). - Type: Beccariodendron grandiflorum Warb.

\section{Regional distribution}

Fig. 10.

Goniothalamus angustifolius (A.C.Sm.) B.Xue \& R.M.K.Saunders

PhytoKeys 32: 33 (Tang et al. 2013). - Polyalthia angustifolia A.C.Sm., Bulletin of the Torrey Botanical Club 70: 538 (Smith 1943). - Type: Fiji, Viti Levu, Naitasiri Province, Tamavua woods, 7 miles from Suva, 9 Aug. 1927, J.W. Gillespie 2198 (holo-: A00039617; iso-: GH00039618).

\section{Regional distribution}

Fiji.

\section{Goniothalamus carolinensis Kaneh.}

Botanical Magazine (Tokyo) 45: 279 (Kanehira 1931). - Type: Palau, Gaspan, Main Island, in forest near the sea, 21 Jul. 1929, R. Kanehira 477 (hololecto-, designated here: FU, Fig. 11; isolecto-: NY00025931). 


\section{Regional distribution}

Palau.

\section{Notes}

Kanehira cited two specimens in the protologue of this species; his numbers 477 and 531, both collected in Palau. Images of the specimens in the Herbarium of Kyushu University (FU) show that either the original field labels or the Flora of the Caroline Islands labels have got transposed between the sheets ( 477 on the field label is mounted with 531 on the FCI label and vice versa). In the lectotype designation above it is the number on the field label that is followed. An annotation of 477 in red indelible pencil on the paper wrapping the material in the packet on the lectotype sheet seems to indicate that it is the Flora of the Caroline Islands labels that are in error. This means that the specimen in US with 477 on a FCI label is probably not an isolectotype.

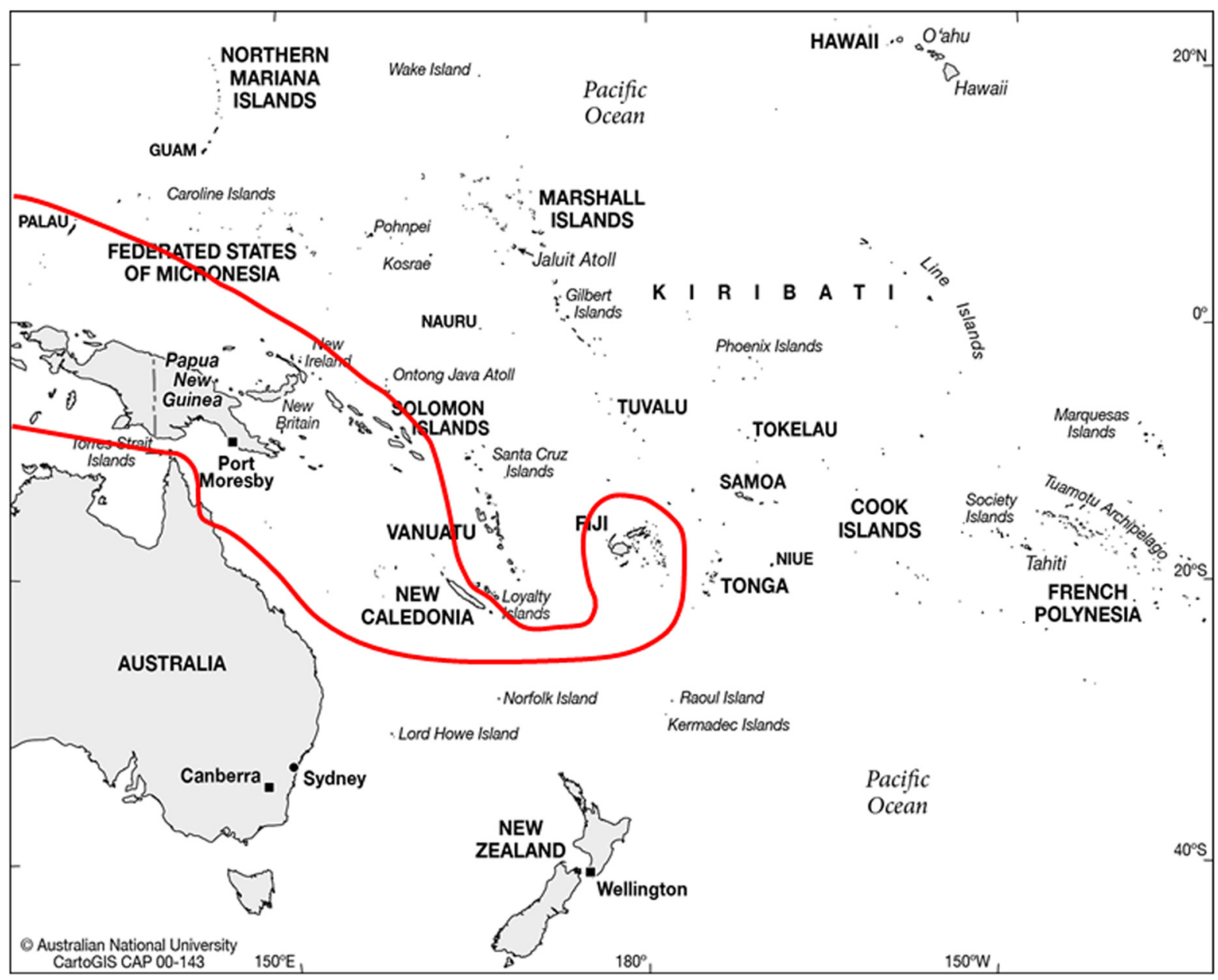

Fig. 10. Regional distribution of the genus Goniothalamus (Annonaceae) in the Pacific. Base map sourced from CartoGIS, College of Asia and the Pacific, The Australian National University, Australia. 


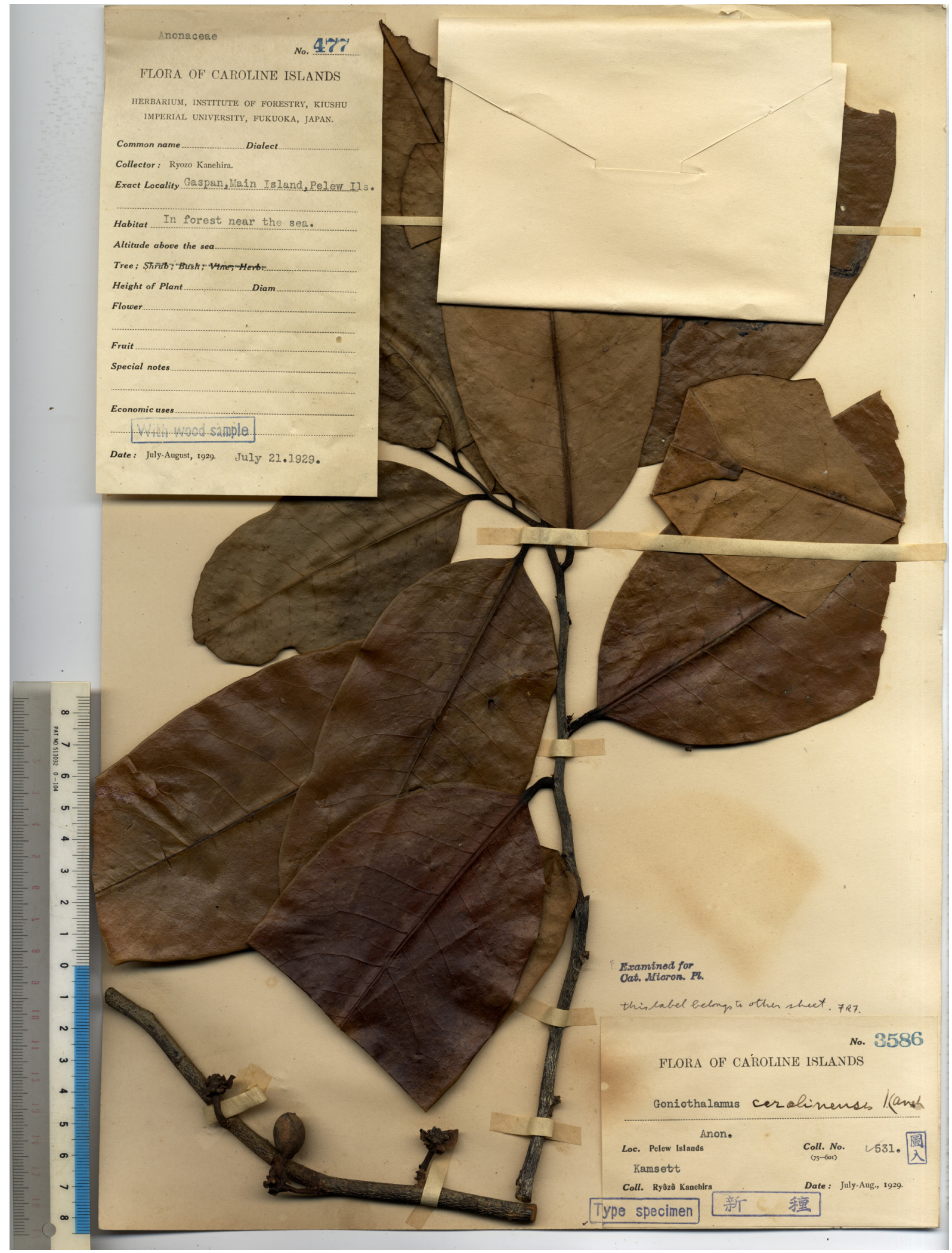

Fig. 11. Lectotype of Goniothalamus carolinensis Kaneh. Image provided by the Herbarium of Kyushu University (FU), Japan. 
Goniothalamus dumontetii R.M.K.Saunders \& Munzinger

Botanical Journal of the Linnean Society 155 (4): 497-503, figs 1-14 (Saunders \& Munzinger 2007). Type: New Caledonia, Grande Terre, Vallée de la Nodela, 18 Oct. 2005, V. Dumontet et al. 558 (holo-: NOU; iso-: $\mathrm{MO}, \mathrm{P}[2$ specs]).

\section{Regional distribution}

New Caledonia.

Goniothalamus grandiflorus (Warb.) Boerl.

Icones Bogorienses 1: 136 (Boerlage 1899). - Beccariodendron grandiflorum Warb., Botanische Jahrbücher für Systematik, Pflanzengeschichte und Pflanzengeographie 13 (3-4): 452 (Warburg 1891). - Type: Papua New Guinea, Kaiser Wilhelmsland, 20 Mar. 1889, F. Hellwig 470 (hololecto-, designated by Diels (1912: 146): B10 0272897; isolecto-: P).

Oxymitra macrantha Hemsl., Hooker's Icones Plantarum 24: tabs 2399-2400 (Hemsley 1895). - Type: Solomon Islands, Florida, Gaemomoli, R.B. Comins 293 (holo-: K000691935).

\section{Regional distribution}

Solomon Archipelago.

\section{Goniothalamus monospermus (A.Gray) R.M.K.Saunders}

Nordic Journal of Botany 29 (6): 676 (Saunders \& Wang 2012). - Richella monosperma A.Gray, Proceedings of the American Academy of Arts and Sciences 2: 325 (Gray 1852). - Oxymitra grayana Baill., Histoire des Plantes 1: 237, figs 285, 286 (Baillon 1868a) nom. illegit. superfl. - Oxymitra monosperma (A.Gray) A.C.Sm., Bulletin of the Bernice P. Bishop Museum 141: 62 (Smith 1936). - Type: Fiji, Ovalau, 1840, Wilkes Explor. Exped. s.n. (hololecto-, designated by Smith (1981: 36): US00098766; isolecto-: GH00339665).

\section{Regional distribution}

Fiji.

Goniothalamus obtusatus (Baill.) R.M.K.Saunders

Nordic Journal of Botany 29 (6): 676 (Saunders \& Wang 2012). - Oxymitra obtusata Baill., Adansonia 8: 178 (Baillon 1868b). - Richella obtusata (Baill.) R.E.Fr., Die natürlichen Pflanzenfamilien ed. 2, 17a (2): 140 (Fries 1959). - Type: New Caledonia, E. Vieillard s.n. (holo-: P).

\section{Regional distribution}

New Caledonia.

\section{Huberantha Chaowasku}

Kew Bulletin 70 (2)-23: 1 (Chaowasku et al. 2015). - Hubera Chaowasku, Phytotaxa 69: 46 (Chaowasku et al. 2012), non Huberia DC. (de Candolle 1828). - Type: Huberantha cerasoides (Roxb.) Chaowasku.

\section{Regional distribution}

Fig. 12. 
Huberantha amoena (A.C.Sm.) Chaowasku

Kew Bulletin 70 (2)-23: 2 (Chaowasku et al. 2015). - Polyalthia amoena A.C.Sm., Journal of the Arnold Arboretum 31: 159 (Smith 1950). - Hubera amoena (A.C.Sm.) Chaowasku, Phytotaxa 69: 47 (Chaowasku et al. 2012). - Type: Fiji, Vanua Levu, Mathuata Province, east of Lambasa, on the summit ridge of Mt. Numbuiloa, 29 Oct. 1947, A.C. Smith 6423 (holo-: A00039619; iso-: BISH, BRI, K, L, P, $\mathrm{S}, \mathrm{US})$.

\section{Regional distribution}

Fiji.

Huberantha asymmetrica I.M.Turner \& Utteridge sp. nov.

See page 9 of this article for description and distribution.

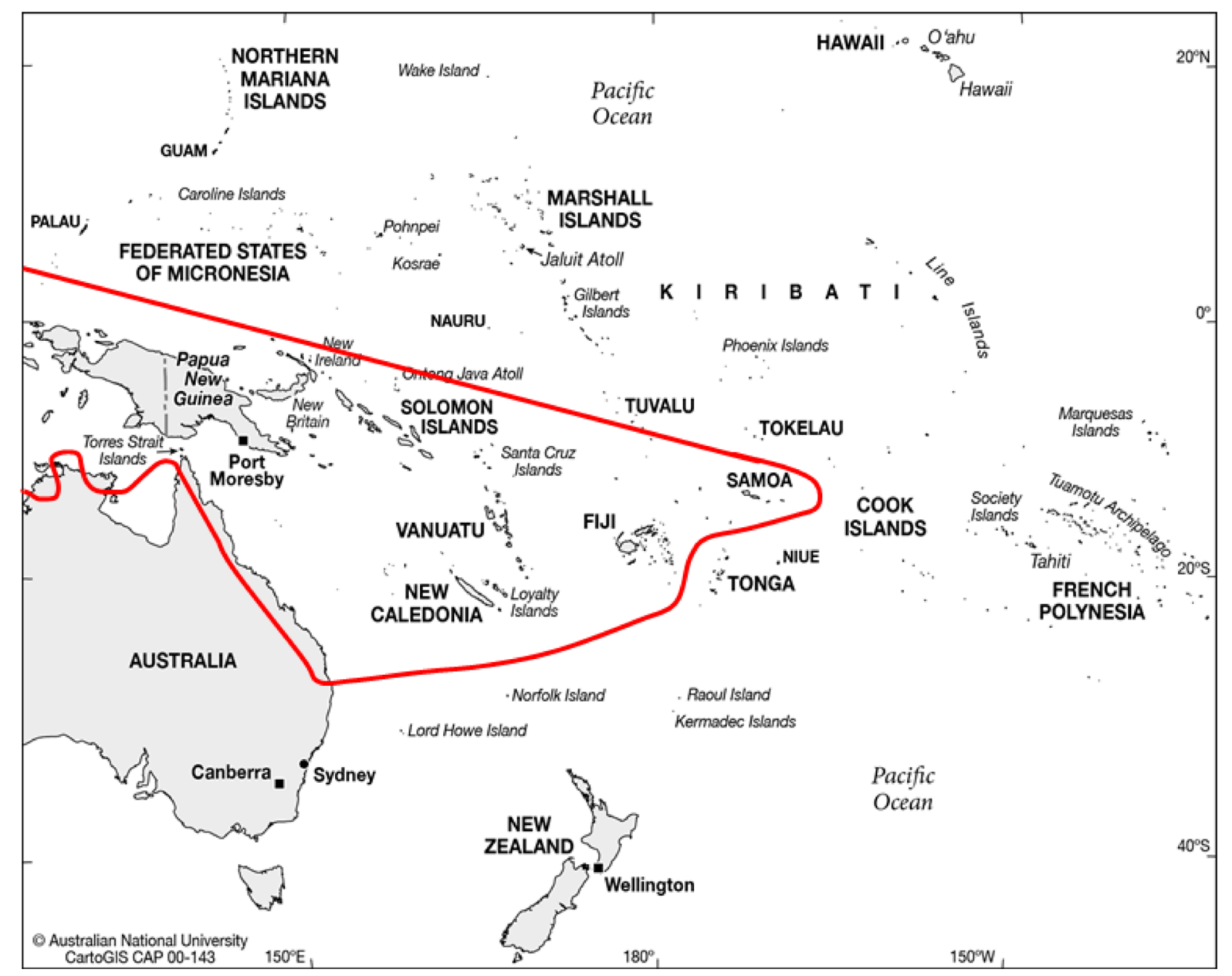

Fig. 12. Regional distribution of the genus Huberantha (Annonaceae) in the Pacific. Base map sourced from CartoGIS, College of Asia and the Pacific, The Australian National University, Australia. 
Huberantha capillata (A.C.Sm.) Chaowasku

Kew Bulletin 70 (2)-23: 2 (Chaowasku et al. 2015). - Polyalthia capillata A.C.Sm., Journal of the Arnold Arboretum 31: 158 (Smith 1950). - Hubera capillata (A.C.Sm.) Chaowasku, Phytotaxa 69: 47 (Chaowasku et al. 2012). - Type: Fiji, Viti Levu, Nandronga \& Navosa Province, on the southern slopes of the Nausori Highlands, in the drainage of Namosi Creek, above Tumbenasolo, 29 May 1947, A.C. Smith 4581 (holo-: A00039620; iso-: BISH, BRI, K, US).

\section{Regional distribution}

Fiji; Solomon Archipelago (?), Santa Cruz Islands, Vanikoro (BSIP 1707, BSIP 1699); Vanuatu, Pentecost Island (Wheatley 101).

\section{Notes}

Some fruiting specimens from the island of Vanikoro in the Santa Cruz group, and one from Pentecost Island in Vanuatu, appear similar to Huberantha capillata, a poorly known species from Fiji. They are referred to the species with some doubt.

Huberantha loriformis (Gillespie) Chaowasku

Kew Bulletin 70 (2)-23: 3 (Chaowasku et al. 2015). - Polyalthia loriformis Gillespie, Bulletin of the Bernice P. Bishop Museum 83: 4, fig. 1 (Gillespie 1931). - Hubera loriformis (Gillespie) Chaowasku, Phytotaxa 69: 49 (Chaowasku et al. 2012). - Type: Fiji, Viti Levu, Naitasiri Province, in the vicinity of Nasinu, 29 Oct. 1927, J.W. Gillespie 3639 (holo-: BISH1011147; iso-: BISH1011148, GH, NY).

\section{Regional distribution}

Fiji.

Huberantha nitidissima (Dunal) Chaowasku

Kew Bulletin 70 (2)-23: 3 (Chaowasku et al. 2015). - Unona nitidissima Dunal, Monographie de la famille des Anonacées: 109, tab. 23 (Dunal 1817). - Polyalthia nitidissima (Dunal) Benth., Flora Australiensis 1: 51 (Bentham 1863). - Hubera nitidissima (Dunal ) Chaowasku, Phytotaxa 69: 50 (Chaowasku et al. 2012). - Type: New Caledonia, s. coll., s.n. (holo-: G00201426).

Unona fulgens Labill., Sertum austro-caledonicum: 57, tab. 56 (de Labillardière 1825). - Type: New Caledonia, J.J.H. de Labillardière s.n. (holo-: P00537614).

Unona nitens F.Muell., Fragmenta phytographiae australiae 3 (17): 2 (von Mueller 1862). - Type: Australia, Northern Territory, Port Darwin, D. Henne s.n. (holo-: MEL2280383).

Popowia novo-guineensis Miq., Annales Musei Botanici Lugduno-Batavi 2: 21 (Miquel 1865). - Type: New Guinea, A. Zippelius s.n. (hololecto-, designated here: U0145973; isolecto-: K000691688).

\section{Regional distribution}

Vanuatu (Kajewski 721, RSNH 3033); New Caledonia. 


\section{Huberantha vitiensis (Seem.) Chaowasku}

Kew Bulletin 70 (2)-23: 3 (Chaowasku et al. 2015). - Polyalthia vitiensis Seem., Flora Vitiensis 1: 4, pl. 3 (Seemann 1865). - Hubera vitiensis (Seem.) Chaowasku, Phytotaxa 69: 51 (Chaowasku et al. 2012). - Type: Fiji, Ovalau, near Port Kinnaird, Jul. 1860, B. Seemann 4 (holo-: K000691678).

Polyalthia pedicellata A.C.Sm., Bulletin of the Bernice P. Bishop Museum 141: 61, fig. 29 (Smith 1936). - Type: Fiji, Vanua Levu, Mt. Mbatini, Thakaundrove, 28 Nov. 1933, A.C. Smith 647 (holo-: BISH; iso-: GH, NY, P, S, US, WIS).

\section{Regional distribution}

Fiji.

Huberantha whistleri I.M.Turner \& Utteridge sp. nov.

See page 12 of this article for description and distribution.

\section{Huberantha sp.}

\section{Regional distribution}

Solomon Islands (BSIP 774, BSIP 3556, BSIP 11467).

\section{Notes}

There is a second Huberantha species from the main islands of the Solomons. It has glabrous twigs and unbeaked ellipsoidal monocarps which distinguish it from Huberantha asymmetrica sp. nov. However, in the absence of flowers it is difficult to be certain that it is not one of the species from New Guinea.

\section{Meiogyne Miq.}

Annales Musei Botanici Lugduno-Batavi 2: 12 (Miquel 1865) nom. cons. - Type: Meiogyne virgata (Blume) Miq.

Fitzalania F.Muell., Fragmenta phytographiae australiae 4: 33 (von Mueller 1863) nom. rej. - Type: Fitzalania heteropetala (F.Muell.) F.Muell.

Ancana F.Muell., Fragmenta phytographiae australiae 5: 27, tab. 35 (von Mueller 1865). - Type: Ancana stenopetala F.Muell.

Ararocarpus Scheff., Annales du Jardin Botanique de Buitenzorg 2: 10 (Scheffer 1881). - Type: Ararocarpus velutinus Scheff.

Oncodostigma Diels, Botanische Jahrbücher für Systematik, Pflanzengeschichte und Pflanzengeographie 49: 143, fig. 2 (Diels 1912). - Type: Oncodostigma leptoneurum Diels.

Guamia Merr., Philippine Journal of Science. Section C, Botany 10: 243 (Merrill 1915). - Type: Guamia mariannae (Saff.) Merr.

Polyaulax Backer, Blumea 5: 492 (Backer 1945). - Type: Polyaulax cylindrocarpa (Burck) Backer.

Chieniodendron Tsiang \& P.T.Li, Acta Phytotaxonomica Sinica 9: 375 (Tsiang \& Li 1964). - Type: Chieniodendron hainanense (Merr.) Tsiang \& P.T.Li. 


\section{Regional distribution}

Fig. 13.

Meiogyne amicorum (A.C.Sm.) B.Xue \& R.M.K.Saunders

Systematic Botany 39 (2): 401 (Xue et al. 2014). - Polyalthia amicorum A.C.Sm., Bulletin of the Bernice P. Bishop Museum 220: 113-115, fig. 9 (Yuncker 1959). - Type: Tonga, Tongatapu, near Pikula, 1 Jun. 1953, T.G. Yuncker 16228 (holo-: US00098654, US00098655; iso-: BISH1000686, NY, U).

\section{Regional distribution}

Tonga.

Meiogyne amygdalina (A.Gray) B.Xue \& R.M.K.Saunders

Systematic Botany 39 (2): 401 (Xue et al. 2014). - Uvaria amygdalina A.Gray, United States Exploring Expedition 15 (1): 31 (Gray 1854). - Polyalthia amygdalina (A. Gray) Gillespie, Bulletin of the Bernice P. Bishop Museum 83: 4 (Gillespie 1931). - Type: Fiji, Ovalau, 1840, Wilkes Explor. Exped. s.n. (hololecto-, designated by Smith (1936: 60): GH00039616; isolecto-: US00104128).

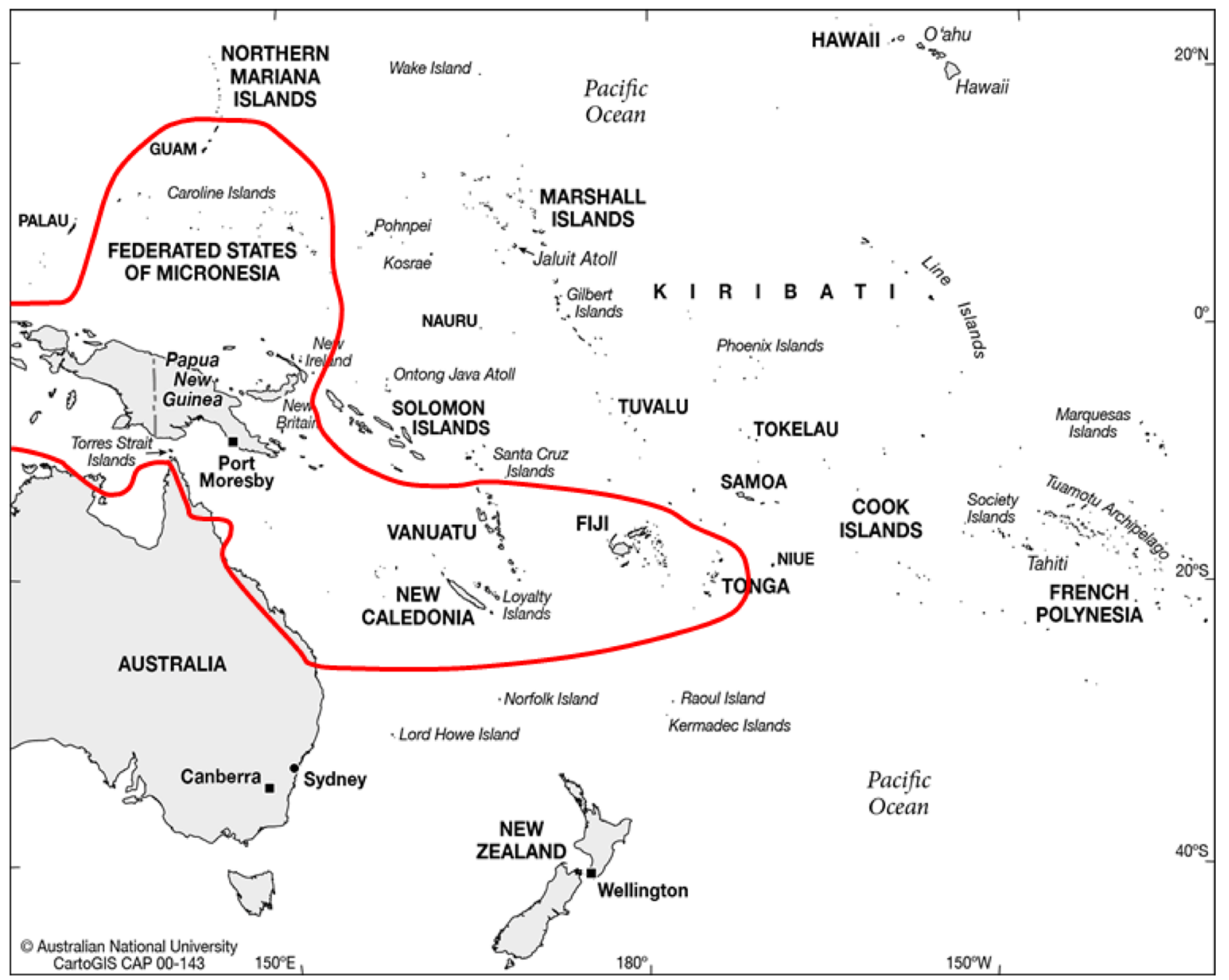

Fig. 13. Regional distribution of the genus Meiogyne (Annonaceae) in the Pacific. Base map sourced from CartoGIS, College of Asia and the Pacific, The Australian National University, Australia. 
Desmos leucanthus A.C.Sm., Journal of the Arnold Arboretum 31: 156 (Smith 1950). - Type: Fiji, Nandronga \& Navosa Province, on the northern part of the Rairaimatuku Plateau between Nandrau and Rewasau, 11 Aug. 1947, A.C. Smith 5613 (holo-: A00039298).

\section{Regional distribution}

Fiji.

Meiogyne baillonii (Guillaumin) Heusden

Bulletin du Muséum national d'Histoire naturelle. Section B, Adansonia: botanique phytochimie 18 (12): 77 (van Heusden 1996). - Uvaria baillonii Guillaumin, Bulletin du Muséum national d'Histoire naturelle 26: 254 (Guillaumin 1920). - Melodorum baillonii (Guillaumin) Guillaumin, Bulletin de la Société Botanique de France 79: 689 (Guillaumin 1932). - Type: New Caledonia, forêts situées au NE de Daaoui de Ero, près de Bourail, 11 Apr. 1869, B. Balansa 1173 (hololecto-, designated by van Heusden (1996: 77): P00057031; isolecto-: K, P00057033, P00057032).

\section{Regional distribution}

New Caledonia.

\section{Meiogyne cylindrocarpa (Burck) Heusden}

Blumea 38: 499 (van Heusden 1994). - Mitrephora cylindrocarpa Burck, Nova Guinea 8: 433 (Burck 1911). - Polyaulax cylindrocarpa (Burck) Backer, Blumea 5: 493 (Backer 1945). - Type: New Guinea, South-West New Guinea, south coast near Okaba, 27 Sep. 1907, B. Branderhorst 107 (hololecto-, designated by Diels (1912: 156): U0000339; isolecto-: A, B, BO, K, L).

Papualthia mariannae Saff., Journal of the Washington Academy of Sciences 2: 459, figs 1-2 (Safford 1912). - Polyalthia mariannae (Saff.) Merr., Philippine Journal of Science. Section C, Botany 9: 83 (Merrill 1914). - Guamia mariannae (Saff.) Merr., Philippine Journal of Science. Section C, Botany 10: 243 (Merrill 1915). - Type: Marianas Islands, Guam, on Pago Road, Jun. 1906, H.L.W. Costenoble s.n. [Herb. Safford no. 1180] (holo-: US00098689; iso-: US).

Oncodostigma wilsonii Guillaumin, Journal of the Arnold Arboretum 12: 224 (Guillaumin 1931). Type: Vanuatu, Aneityum, Anelgauhat Bay, Sep. 1929, J.P. Wilson 986 (holo-: P00636932; iso-: A, B, $\mathrm{K}, \mathrm{NY}$ ).

\section{Regional distribution}

Northern Marianas, Guam, Vanuatu.

Meiogyne dumetosa (Guillaumin) Heusden

Bulletin du Muséum national d'Histoire naturelle. Section B, Adansonia: botanique phytochimie 18 (12): 79 (van Heusden 1996). - Uvaria dumetosa Vieill. ex Guillaumin, Bulletin du Muséum national d'Histoire naturelle, sér. 214 (2): 145 (Guillaumin 1942). - Type: New Caledonia, sommet de la montagne de Gomonen, près Gatope, E. Vieillard 2288 (hololecto-, designated by van Heusden (1996: 79): P00057037; isolecto-: GH, K, L, P00057038, P00057039).

\section{Regional distribution}

New Caledonia. 
Meiogyne laddiana (A.C.Sm.) B.Xue \& R.M.K.Saunders

Systematic Botany 39 (2): 401 (Xue et al. 2014). - Polyalthia laddiana A.C.Sm., Bulletin of the Bernice P. Bishop Museum 141: 60, fig. 28 (Smith 1936). - Type: Fiji, Fulanga, 22 Feb. 1934, A.C. Smith 1147 (holo-: BISH; iso-: GH, K, NY, P, S, US, WIS).

\section{Regional distribution}

Fiji.

\section{Notes}

The only part of the holotype in BISH that could not be traced recently was a wood specimen (B. Kennedy, pers. com.).

Meiogyne lecardii (Guillaumin) Heusden

Bulletin du Muséum national d'Histoire naturelle. Section B, Adansonia: botanique phytochimie 18 (12): 80 (van Heusden 1996). - Unona lecardii Guillaumin, Bulletin de la Société Botanique de France 79: 690 (Guillaumin 1932). - Desmos lecardii (Guillaumin) R.E.Fr., Die natürlichen Pflanzenfamilien 17aII: 90 (Fries 1959). - Type: New Caledonia, Ouraï, 25 Sep. 1876, T. Lécard 50-73A (hololecto-, designated by van Heusden (1996: 80): P00057034; isolecto-: P00057035, P00057036).

\section{Regional distribution}

New Caledonia.

Meiogyne habrotricha (A.C.Sm.) B.Xue \& R.M.K.Saunders

Systematic Botany 39 (2): 401 (Xue et al. 2014). - Polyalthia habrotricha A.C.Sm., Journal of the Arnold Arboretum 31: 157 (Smith 1950). - Type: Fiji, Viti Levu, Nandronga \& Navosa Province, on the northern portion of the Rairaimatuku Plateau, between Nandrau and Rewasau, 11 Aug. 1947, A.C. Smith 5614 (holo-: A00019830).

\section{Regional distribution}

Fiji.

Meiogyne insularis (A.C.Sm.) D.C.Thomas, B.Xue \& R.M.K.Saunders

Systematic Botany 39 (2): 401 (Xue et al. 2014). - Desmos insularis A.C.Sm., Sargentia 1: 31 (Smith 1942). - Polyalthia insularis (A.C.Sm.) A.C.Sm., Allertonia 1: 351 (Smith 1978). Meiogyne stenopetala (F.Muell.) Heusden subsp. insularis (A.C.Sm.) Heusden, Blumea 38 (2): 507 (van Heusden 1994). Type: Fiji, Viti Levu, Mba Province, near Korovou, east of Tavua, 1 Apr. 1941, O. Degener 14968 (holo- : A00019829; iso-: BISH1000666, F, K, L, MICH, P, S, US, WIS).

\section{Regional distribution}

Fiji. 


\section{Meiogyne punctulata (Baill.) I.M.Turner \& Utteridge comb. nov.} urn:Isid:ipni.org:names:77164171-1

Basionym: Melodorum punctulatum Baill., Adansonia 10: 107 (Baillon 1871). - Fissistigma punctulatum (Baill.) Merr., Philippine Journal of Science, Section C, Botany 15: 135 (Merrill 1919). - Type: New Caledonia, Sommet du Nékou, au dessus de Bourail, ca 600 m a.s.1., Mar. 1869, B. Balansa 1174 (holoneo-, designated here: P02006574; isoneo-: A00353979, P02006572, P02006573).

Unona tiebaghiensis Däniker, Vierteljahrsschrift der Naturforschenden Gesellschaft in Zürich 76: 161 (Däniker 1931). - Meiogyne tiebaghiensis (Däniker) Heusden, Bulletin du Muséum national d'Histoire naturelle. Section B, Adansonia: botanique phytochimie 18 (1-2): 81 (van Heusden 1996). - Type: New Caledonia, am Abhang des Tiebaghi-massifs gegen Nordosten, 14 Mar. 1925, A.U. Däniker 1431 (holo-: Z000000864; iso-: P, Z000000862, Z000000863, Z000000865).

\section{Regional distribution}

New Caledonia.

\section{Notes}

Baillon described Melodorum punctulatum from New Caledonia. The reference to Pancher in the opening sentence of the protologue is the only clue to the type of the name. Guillaumin (1932) reported that Baillon's type was lost; as did van Heusden (1996) who treated the name as dubious. She stated that Baillon's description did not "fit exactly any of the "varieties" of Meiogyne tiebaghiense". As an exact fit is not required, rather a lack of serious conflict between the description and the type, we feel Baillon's name cannot simply be ignored and make a new combination for it in Meiogyne. We follow the suggestion of Guillaumin (1932) that Balansa 1174 can be considered representative of Baillon's species and designate the duplicate in the Paris Herbarium with Balansa's original label as neotype. Johnson et al. (2013) chose a similar action in the case of Xylopia pancheri Baill. where the Pancher type to a Baillon name has also been lost.

\section{Monoon Miq.}

Annales Musei Botanici Lugduno-Batavi 2: 15 (Miquel 1865). - Lectotype designated by Saunders \& Xue (2011: 236): Monoon lateriflorum (Blume) Miq.

Enicosanthum Becc., Nuovo Giornale Botanico Italiano 3: 183 (Beccari 1871). - Type: Enicosanthum paradoxum Becc.

Marcuccia Becc., Nuovo Giornale Botanico Italiano 3: 181, tab. 3 (Beccari 1871). - Type: Marcuccia grandiflora Becc.

Griffithia Maingay ex King, Annals of the Royal Botanic Garden (Calcutta) 4: 8 (King 1893), non Griffithia Wight \& Arn. (Wight \& Arnott 1834). - Griffithianthus Merr., Philippine Journal of Science, Section C, Botany 10: 231 (Merrill 1915). - Lectotype designated by Merrill (1915: 231): Griffithia magnoliipetala Maingay ex King.

Woodiella Merr., Journal of the Straits Branch of the Royal Asiatic Society 85: 187 (Merrill 1922), non Woodiella Sacc. \& P.Syd. (Sydow 1899). - Woodiellantha Rauschert, Taxon 31: 555 (Rauschert 1982). - Type: Woodiella sympetala Merr. 
Cleistopetalum H.Okada, Acta Phytotaxonomica et Geobotanica 47: 4 (Okada 1996). - Type: Cleistopetalum borneense H.Okada.

\section{Regional distribution}

Fig. 14.

Monoon merrillii (Kaneh.) I.M.Turner \& Utteridge comb. nov.

urn:lsid:ipni.org:names:77164172-1

Basionym: Polyalthia merrillii Kaneh., Flora Micronesica: 108-109, fig. 30 (Kanehira 1933a). - Type: Palau, Tôdaiyama [Pelew Island], a small coral island near Korror, in primary forests at $200 \mathrm{~m}$ a.s.l., Aug. 1932, R. Kanehira 2025 (hololecto-, designated here: FU, sheet bearing the original field label mounted on the top left; isolecto-: FU, US00098670; Fig. 15).

\section{Regional distribution}

Palau.

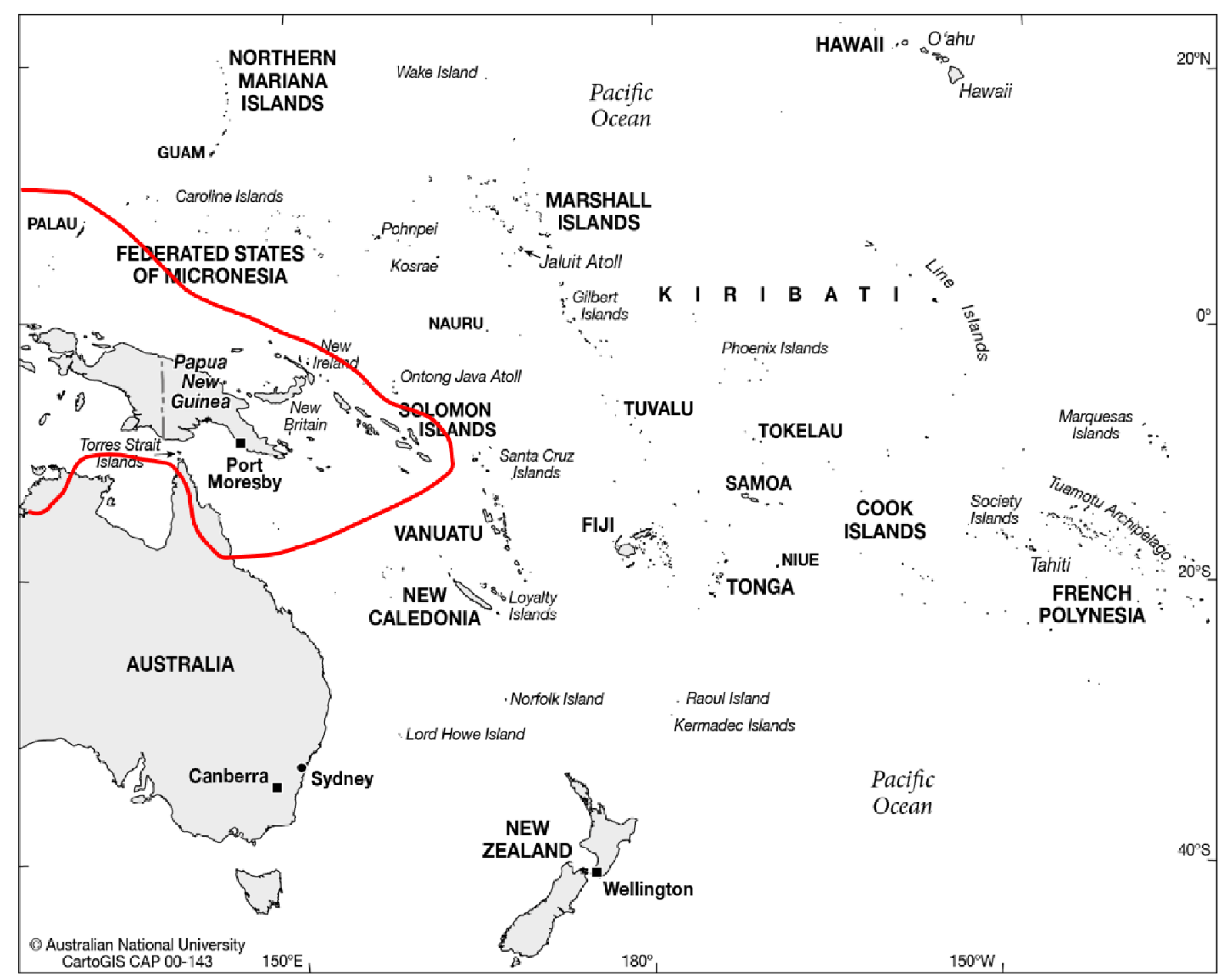

Fig. 14. Regional distribution of the genus Monoon (Annonaceae) in the Pacific. Base map sourced from CartoGIS, College of Asia and the Pacific, The Australian National University, Australia. 


\section{Notes}

Originally published in Japanese, a Latin description appeared in print soon after (Kanehira 1933b: 669670). The species is apparently still only known from Kanehira's type collection and the flowers remain uncollected. Images were available to us of type material from the Herbarium of Kyushu University in Japan (FU), and US. The herringbone secondary venation with decurrent insertion to the midrib, scalariform tertiary venation and the form of the fruits indicates that the species belongs in Monoon rather than Polyalthia s. str., so we make a new combination for it here. Interestingly the Palau species has unusual asymmetic leaf bases similar to those of Monoon pachypetalum sp. nov. from New Guinea. The distinctly stipitate fruits of M. merrillii show that it is not the same species as Monoon pachypetalum sp. nov.

Monoon salomonicum I.M.Turner \& Utteridge sp. nov.

See page 6 of this article for description and distribution.

\section{Polyalthia Blume}

Flora Javae nec non insularum adjacentium 28-29: 68 (Blume 1830). - Lectotype designated by Hutchinson (1923: 259): Polyalthia subcordata (Blume) Blume.

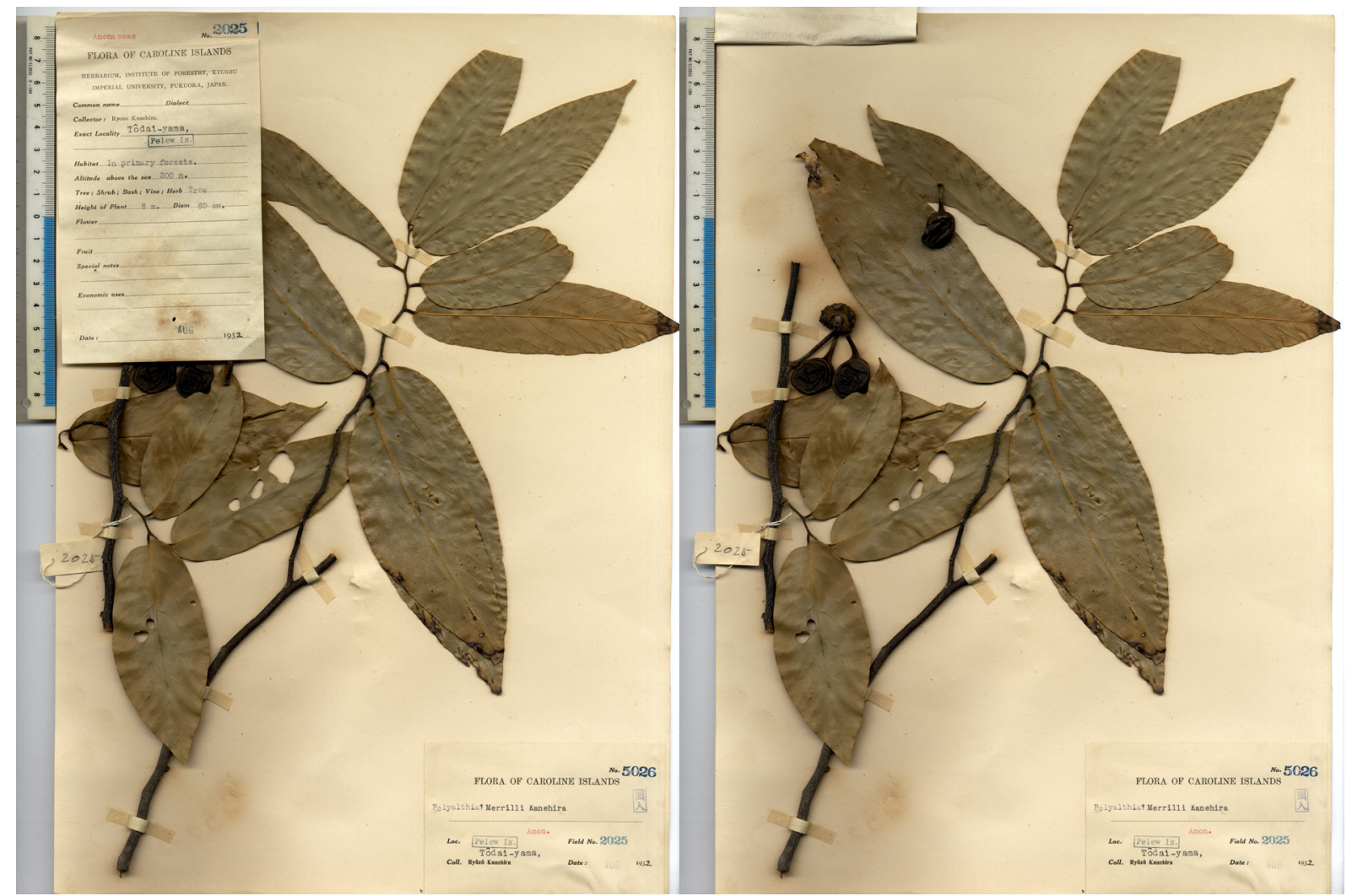

Fig. 15. Lectotype of Polyalthia merrillii Kaneh. Right-hand image has the label folded back to reveal the obscured parts of the specimen. Images provided by the Herbarium of Kyushu University (FU), Japan. 
Sphaerothalamus Hook.f., Transactions of the Linnean Society of London 23: 156 (Hooker 1860). Type: Sphaerothalamus insignis Hook.f.

Haplostichanthus F.Muell., Victorian Naturalist 7: 180 (von Mueller 1891). - Type: Haplostichanthus johnsonii F.Muell.

Papualthia Diels, Botanische Jahrbücher für Systematik, Pflanzengeschichte und Pflanzengeographie 49: 138 (Diels 1912) - Lectotype designated by Fries (1959: 97): Papualthia pilosa Diels.

\section{Regional distribution}

Fig. 16.

Polyalthia longirostris (Scheff.) B.Xue \& R.M.K.Saunders

Taxon 61 (5): 1034 (Xue et al. 2012). - Goniothalamus longirostris Scheff., Annales du Jardin Botanique de Buitenzorg 1: 4 (Scheffer 1876). - Trivalvaria longirostris (Scheff.) Scheff., Annales du Jardin Botanique de Buitenzorg 2: 28 (Scheffer 1881). - Papualthia longirostris (Scheff.) Diels, Botanische Jahrbücher für Systematik, Pflanzengeschichte und Pflanzengeographie 49: 140 (Diels

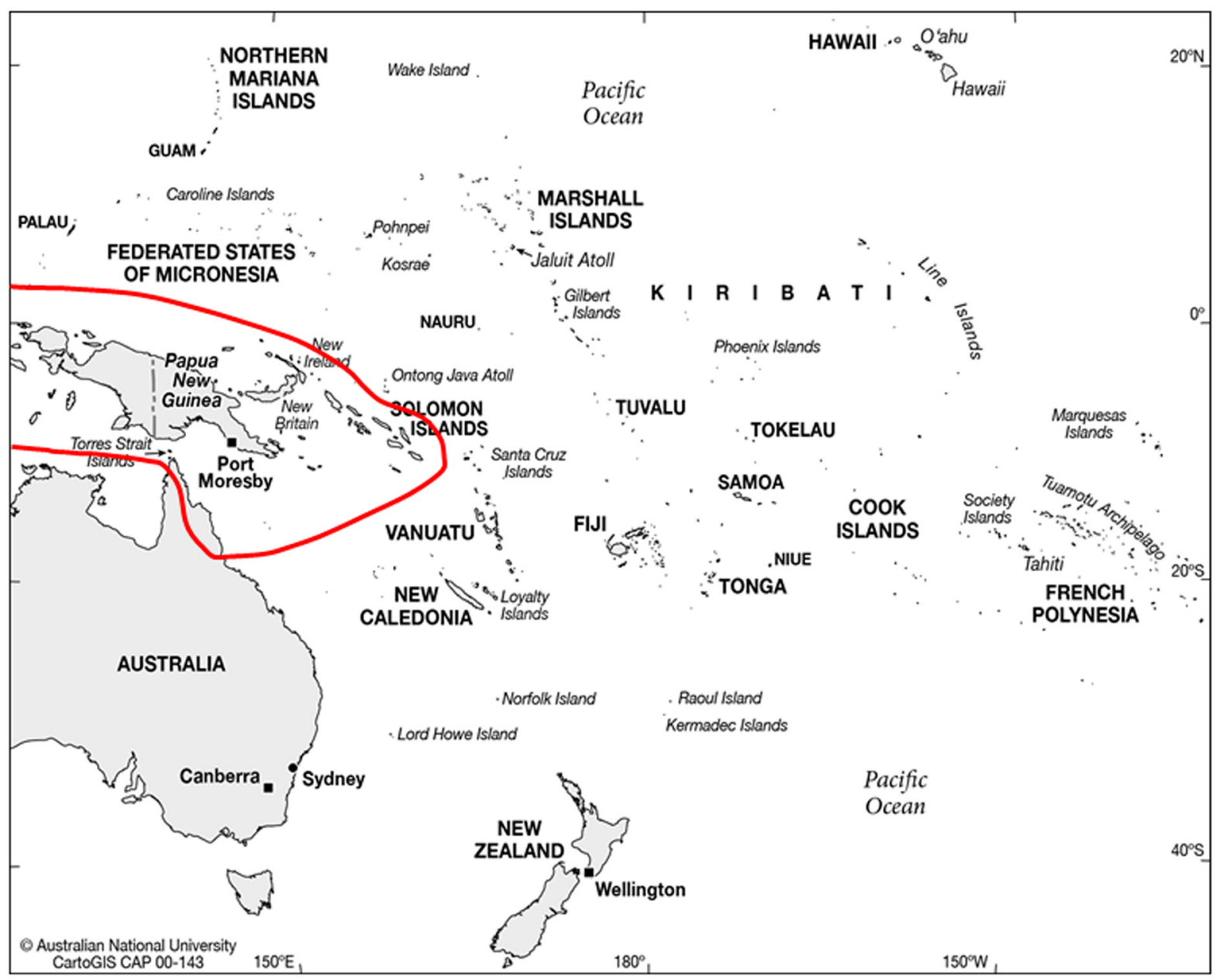

Fig. 16. Regional distribution of the genus Polyalthia (Annonaceae) in the Pacific. Base map sourced from CartoGIS, College of Asia and the Pacific, The Australian National University, Australia. 
1912). - Haplostichanthus longirostris (Scheff.) Heusden, Blumea 39 (1-2): 228 (van Heusden 1994). - Type: New Guinea, Doré, J.E. Teijsmann s.n. (holo-: BO).

Melodorum micranthum Warb., Botanische Jahrbücher für Systematik, Pflanzengeschichte und Pflanzengeographie 18: 190 (Warburg 1893). - Type: Papua New Guinea, Kaiser Wilhelmsland, [Finschhafen], 15 Feb. 1889, F. Hellwig 370 (hololecto-, designated by Diels (1912: 141): B; isolecto-: MPU, K).

Cyathostemma grandifolium Lauterb. \& K.Schum., Die Flora der Deutschen Schutzgebiete in der Südsee: 318 (Schumann \& Lauterbach 1900). - Papualthia grandifolia (Laut. \& K. Schum.) Diels, Botanische Jahrbücher für Systematik, Pflanzengeschichte und Pflanzengeographie 49: 139 (Diels 1912). - Type: Papua New Guinea, Kaiser Wilhelmsland, Ramu-Station, 22 Jun. 1899, H. Rodatz \& H. Klink 26 (holo-: B10 0272881).

Goniothalamus inaequilaterus Lauterb. \& K.Schum., Die Flora der Deutschen Schutzgebiete in der Südsee: 322 (Schumann \& Lauterbach 1900). - Type: New Guinea, Finschhafen, 3 Jan. 1890, C. Lauterbach 1374 (hololecto-, designated by Diels (1912: 141): B10 0272883).

Goniothalamus auriculatus Burck, Nova Guinea 8 (3): 432 (Burck 1911). - Papualthia auriculata (Burck) Diels, Botanische Jahrbücher für Systematik, Pflanzengeschichte und Pflanzengeographie 49: 139 (Diels 1912). - Type: Indonesia, Lorentz R. near Bivak Island, 9 May 1907, G.M. Versteeg 1038 (hololecto-, designated by Diels (1912: 139): U; isolecto-: A, B, K, L).

Papualthia rudolphi Diels, Botanische Jahrbücher für Systematik, Pflanzengeschichte und Pflanzengeographie 49: 139 (Diels 1912). - Type: Papua New Guinea, Kaiser Wilhelmsland; in den Wäldern des Kani-Gebirges, 4 Jan. 1908, R. Schlechter 17138 (holo-: B10 0272885).

Papualthia roemeri Diels, Botanische Jahrbücher für Systematik, Pflanzengeschichte und Pflanzengeographie 49: 141 (Diels 1912). - Type: Indonesia, Lorentz River, 7 Oct. 1909, L.S.A.M. von Römer 465 (holo-: U; iso-: L).

Papualthia pilosa Diels, Botanische Jahrbücher für Systematik, Pflanzengeschichte und Pflanzengeographie 49: 141 (Diels 1912). - Type: Papua New Guinea, Kaiser Wilhelmsland, Baum in den Wäldern des Gati-Berges, 17 Dec. 1907, R. Schlechter 16988 (holo-: B10 0272886; iso-: P).

Papualthia micrantha Diels, Botanische Jahrbücher für Systematik, Pflanzengeschichte und Pflanzengeographie 52: 182 (Diels 1915). - Type: Papua New Guinea, Lager 3, Mai Fluss, 22 May 1912, C.L. Ledermann 7349 (hololecto-, designated by van Heusden (1994: 229): B10 0272880; isolecto-: K).

\section{Regional distribution}

Solomon Archipelago (RSS 37, RSS 6007, BSIP 8738, BSIP 8987).

\section{Notes}

The Solomons' material was included in Haplostichanthus longirostris by van Heusden (1994) - an extremely variable species from New Guinea and the Solomons when considered in van Heusden's very broadly circumscribed sense. Haplostichanthus was reduced to Polyalthia s. str. by Xue et al. (2012). 


\section{Popowia Endl.}

Genera plantarum secundum ordines naturalis disposita: 831 (Endlicher 1839). - Type: Popowia pisocarpa (Blume) Endl.

\section{Regional distribution}

Fig. 17.

Popowia cf. pisocarpa (Blume) Endl.

\section{Regional distribution}

Solomon Archipelago (BSIP 11563, BSIP 11686).

\section{Notes}

The presence of Popowia in the Solomon Islands can be confirmed from the herbarium material available. These specimens have previously been assigned to Popowia pisocarpa. Moeljono (2012) did not record

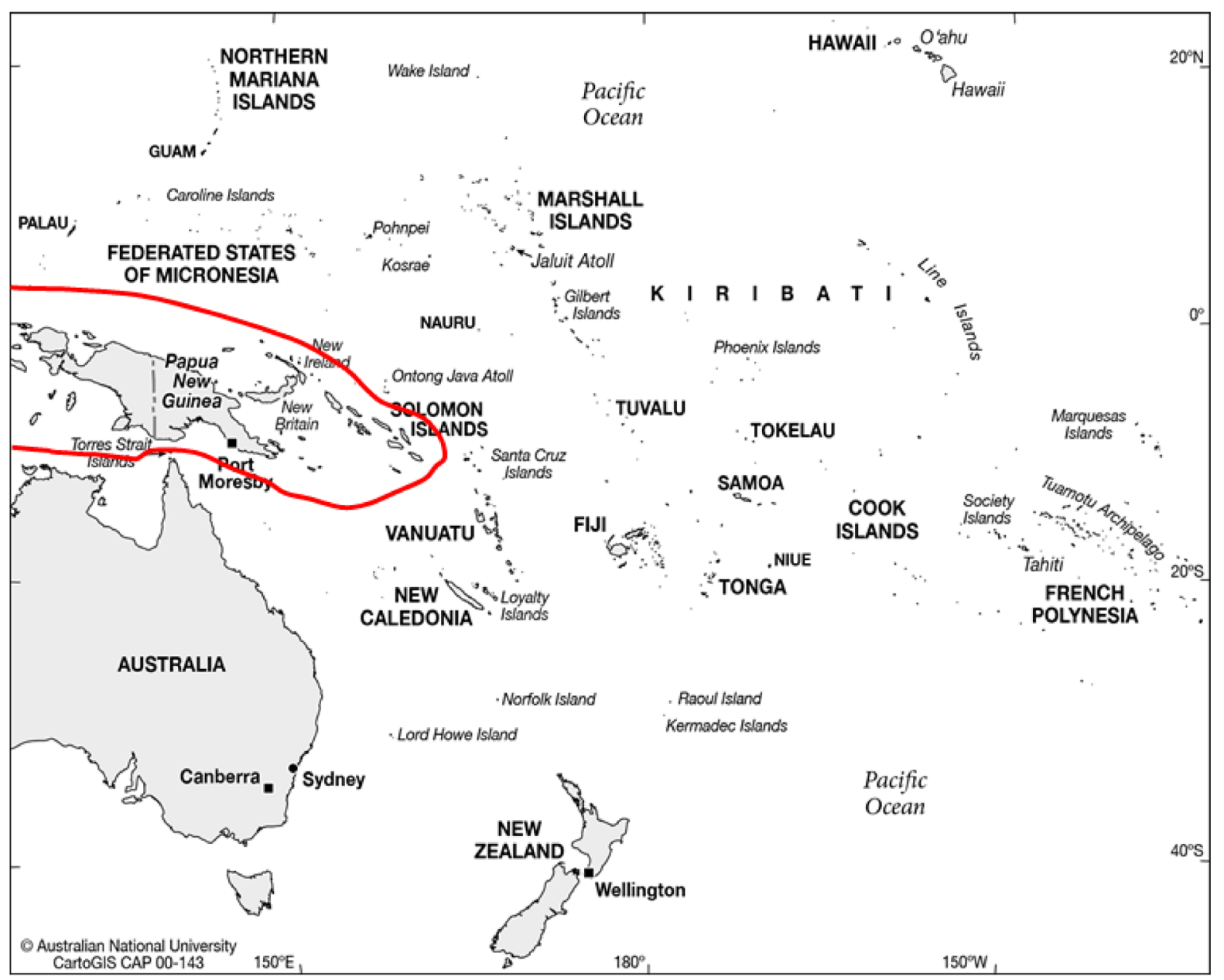

Fig. 17. Regional distribution of the genus Popowia (Annonaceae) in the Pacific. Base map sourced from CartoGIS, College of Asia and the Pacific, The Australian National University, Australia. 
Popowia pisocarpa from mainland New Guinea or from the Pacific Islands, so the identity of the plant from the Solomons remains doubtful.

\section{Uvaria L.}

Species Plantarum 1: 536 (Linnaeus 1753). - Narum Adanson, Familles des plantes 2: 365 (Adanson 1763) nom. illegit. superfl. - Uva Kuntze, Revisio generum plantarum: 7 (Kuntze 1891) nom. illegit. superfl. - Lectotype designated by Hutchinson (1923: 256): Uvaria zeylanica L.

Marenteria Petit-Thouars, Genera nova madagascariensia: 18 (du Petit-Thouars 1806). - Type: Not designated.

Cyathostemma Griff., Notulae ad plantas asiaticas 4: 707 (Griffith 1854). - Type: Cyathostemma viridiflorum Griff.

Ellipeia Hook.f. \& Thomson, Flora Indica: 104 (Hooker \& Thomson 1855). - Type: Ellipeia cuneifolia Hook.f. \& Thomson.

Anomianthus Zoll., Linnaea 29: 324 (Zollinger 1858). - Type: Anomianthus heterocarpus (Blume) Zoll.

Tetrapetalum Miq., Annales Musei Botanici Lugduno-Batavi 2: 1 (Miquel 1865). - Type: Tetrapetalum volubile Miq.

Rauwenhoffia Scheff., Annales du Jardin botanique de Buitenzorg 2: 21 (Scheffer 1881). - Lectotype designated by Hutchinson (1923: 257): Rauwenhoffia siamensis Scheff.

Uvariella Ridl., The Flora of the Malay Peninsula 1: 22, 35 (Ridley 1922). - Type: Uvariella leptopoda (King) Ridl.

Ellipeiopsis R.E.Fr., Arkiv för Botanik 3: 41 (Fries 1953). - Lectotype designated by Fries (1959: 49): Ellipeiopsis ferruginea (Buch.-Ham. ex Hook. f. \& Thomson) R.E.Fr.

Xylopiastrum Roberty, Bulletin de l'Institut Français d'Afrique Noire 15: 1397 (Roberty 1953). - Type: Xylopiastrum macrocarpum (DC. ex Dunal) Roberty.

Dasoclema J.Sinclair, Gardens' Bulletin, Singapore 14: 273 (Sinclair 1955). - Type: Dasoclema siamensis (Craib) J.Sinclair.

Balonga Le Thomas, Adansonia ser. 2, 8: 106, tab. 1 (Le Thomas 1968). - Type: Balonga buchholzii (Engl. \& Diels) Le Thomas.

\section{Regional distribution}

Fig. 18.

Uvaria cf. rosenbergiana Scheff.

\section{Regional distribution}

Solomon Archipelago (BSIP 11320, J.H.L. Waterhouse 409B).

\section{Notes}


The Uvaria material from the Solomons has generally been referred to Uvaria rosenbergiana Scheff., a species described from New Guinea. The correct name for the Solomon plant will only become clear after revision of the genus in the Asia-Pacific Region.

\section{Xylopia L.}

Systema naturae ed. 10, 2: 1241, 1250, 1378 (Linnaeus 1759) nom. cons. - Type: Xylopia muricata L.

Xylopicrum Browne, The civil and natural history of Jamaica in three parts: 250, tab. 5 fig. 2 (Browne 1756) nom. rej. - Type: Not designated.

Unona L.f., Supplementum plantarum systematis vegetabilium: 44, 270 (Linnaeus 1782). - Habzelia A.DC., Mémoires de la Société de Physique et d'Histoire Naturelle de Genève 5: 207 (de Candolle 1832) nom. illegit. superfl. - Type: Unona discreta L.f.

Coelocline A.DC., Mémoires de la Société de Physique et d'Histoire Naturelle de Genève 5: 208 (de Candolle 1832). - Type: Coelocline acutiflora (Dunal) A.DC.

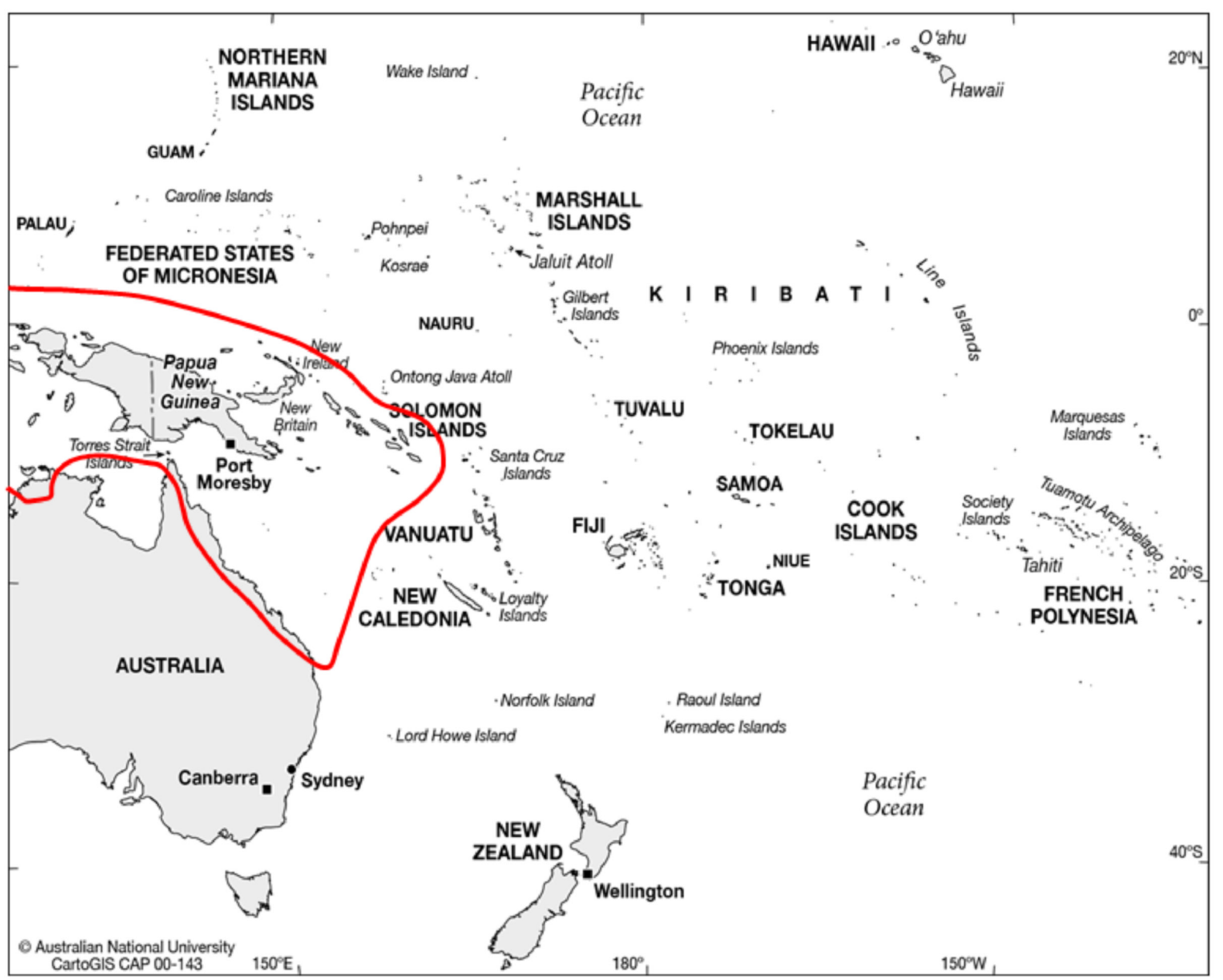

Fig. 18. Regional distribution of the genus Uvaria (Annonaceae) in the Pacific. Base map sourced from CartoGIS, College of Asia and the Pacific, The Australian National University, Australia. 
Patonia Wight, Illustrations of Indian botany 1: 18 (Wight 1836). - Lectotype (designated by van Setten \& Maas 1990: 677): Patonia parvifolia Wight.

Parartabotrys Miq., Flora van Nederlandsch Indië. Supplementum primum. Prodromus florae sumatranae: 374 (Miquel 1861). - Type: Parartabotrys sumatranus Miq.

Pseudannona Saff., Journal of the Washington Academy of Sciences 3: 17 (Safford 1913). - Type: Pseudannona amplexicaulis (Lam.) Saff.

\section{Regional distribution}

Fig. 19.

\section{Xylopia degeneri A.C.Sm.}

Sargentia 1: 32 (Smith 1942). - Type: Fiji, Viti Levu, Serua Province, near Vatutavathe, vicinity of Ngaloa, 5 May 1941, O. Degener 15204 (holo-: A00039731; iso-: NY).

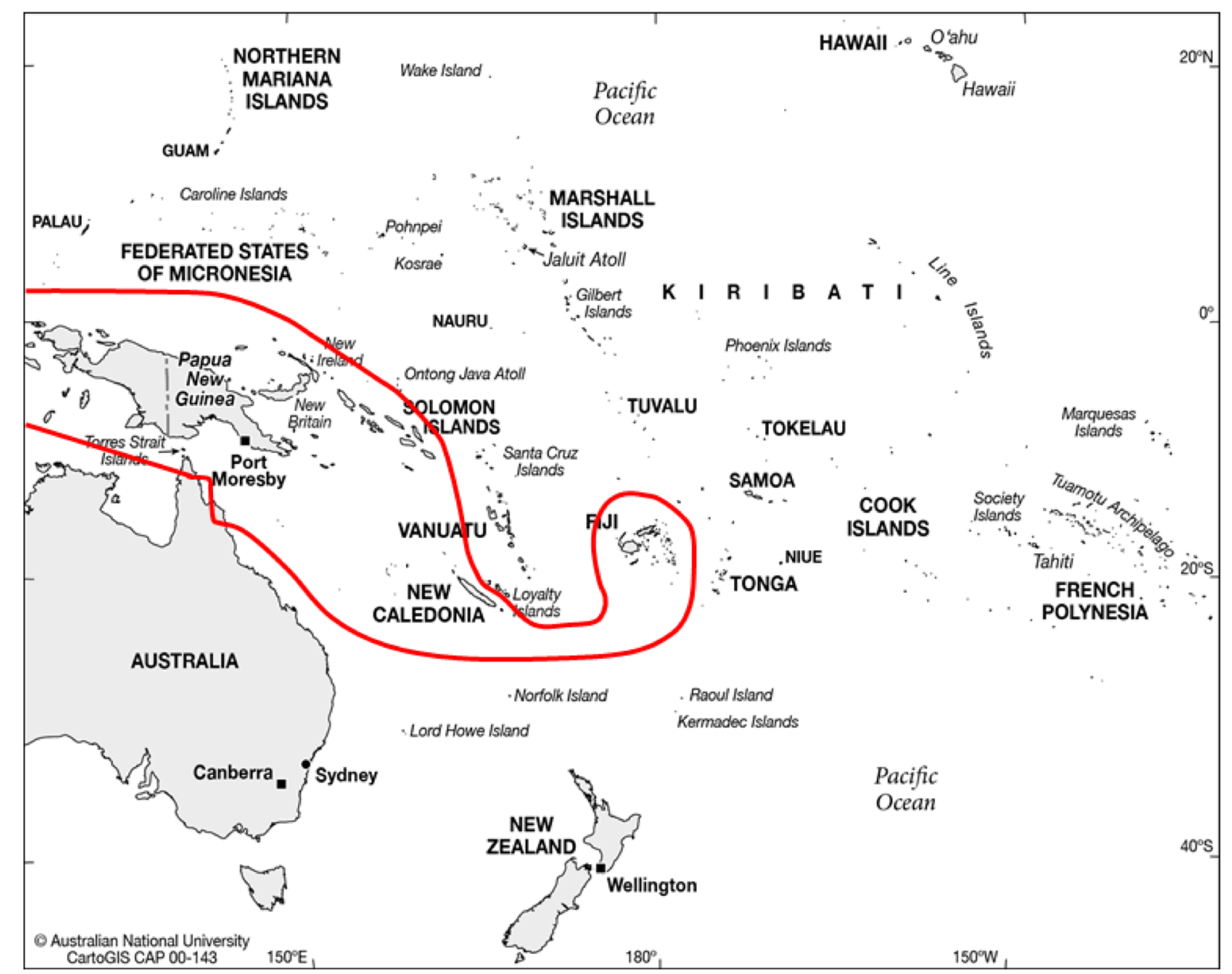

Fig. 19. Regional distribution of the genus Xylopia (Annonaceae) in the Pacific. Base map sourced from CartoGIS, College of Asia and the Pacific, The Australian National University, Australia. 


\section{Regional distribution}

Fiji.

\section{Xylopia dibaccata Däniker}

Vierteljahrsschrift der Naturforschenden Gesellschaft in Zürich 76: 161 (Däniker 1931). - Type: NeuCaledonien, im Tälchen zwischen den beiden Kaalagipfeln, 28 Feb. 1925, A.U. Däniker 1281 (holo-: Z; iso-: $\mathrm{Z}[2$ specs]).

\section{Regional distribution}

New Caledonia.

\section{Xylopia pacifica A.C.Sm.}

Bulletin of the Torrey Botanical Club 70: 538 (Smith 1943). - Type: Fiji, Viti Levu, Naitasiri Province, near Tholo-i-suva, 16 Jan. 1939, DA 2654 [B.E.V. Parham leg.] (holo-: A00039732; iso-: BISH, SUVA, US).

\section{Regional distribution}

Fiji.

\section{Xylopia pallescens Baill.}

Adansonia 11: 178 (Baillon 1874). - Type: New Caledonia, Oritur in Austro-Caledoniae collibus ferrugineis ad orientem Messioncoué, prope Port Bouquet, Dec. 1869, B. Balansa 1776 (holo-: P00507382; iso-: P00507383).

\section{Regional distribution}

New Caledonia.

\section{Xylopia pancheri Baill.}

Adansonia 11: 177, 178 (Baillon 1874). - Type: New Caledonia, bords de la Kouvélè, près de Koé, 30 Jan. 1869, B. Balansa 1175 (holoneo-, designated by Johnson et al. (2013: 210): P00507380; isoneo-: K, P00507379, P00507381).

\section{Regional distribution}

New Caledonia.

\section{Xylopia papuana Diels}

Botanische Jahrbücher für Systematik, Pflanzengeschichte und Pflanzengeographie 52: 180 (Diels 1915). - Type: Papua New Guinea, Sepik River, Pionierlager am Sepik, 15 May 1912, C. Ledermann 7276 (hololecto-, designated here: B10 0249557; isolecto-: K000574759).

\section{Regional distribution}

Solomon Archipelago (BSIP 18475, BSIP 1528, BSIP 7566, BSIP 8772). 


\section{Xylopia peekelii Diels}

Notizblatt des Botanischen Gartens und Museums zu Berlin-Dahlem 11: 83 (Diels 1931). - Type: Papua New Guinea [in insula Neu-Mecklenburg: Lamekot, Buschland, Apr. 1924], G. Peekel 947 (holo-: B10 0249553).

\section{Regional distribution}

Solomon Archipelago (BSIP 15747, BSIP 15709, BSIP 15037).

\section{Xylopia vieillardii Baill.}

Adansonia 8: 202 (Baillon 1868b). - Type: Novae-Caledoniae montium declivitatibus ubi haud procul a Balade, E. Vieillard 95 (holo-: P00507322; iso-: P00507330, P00507321).

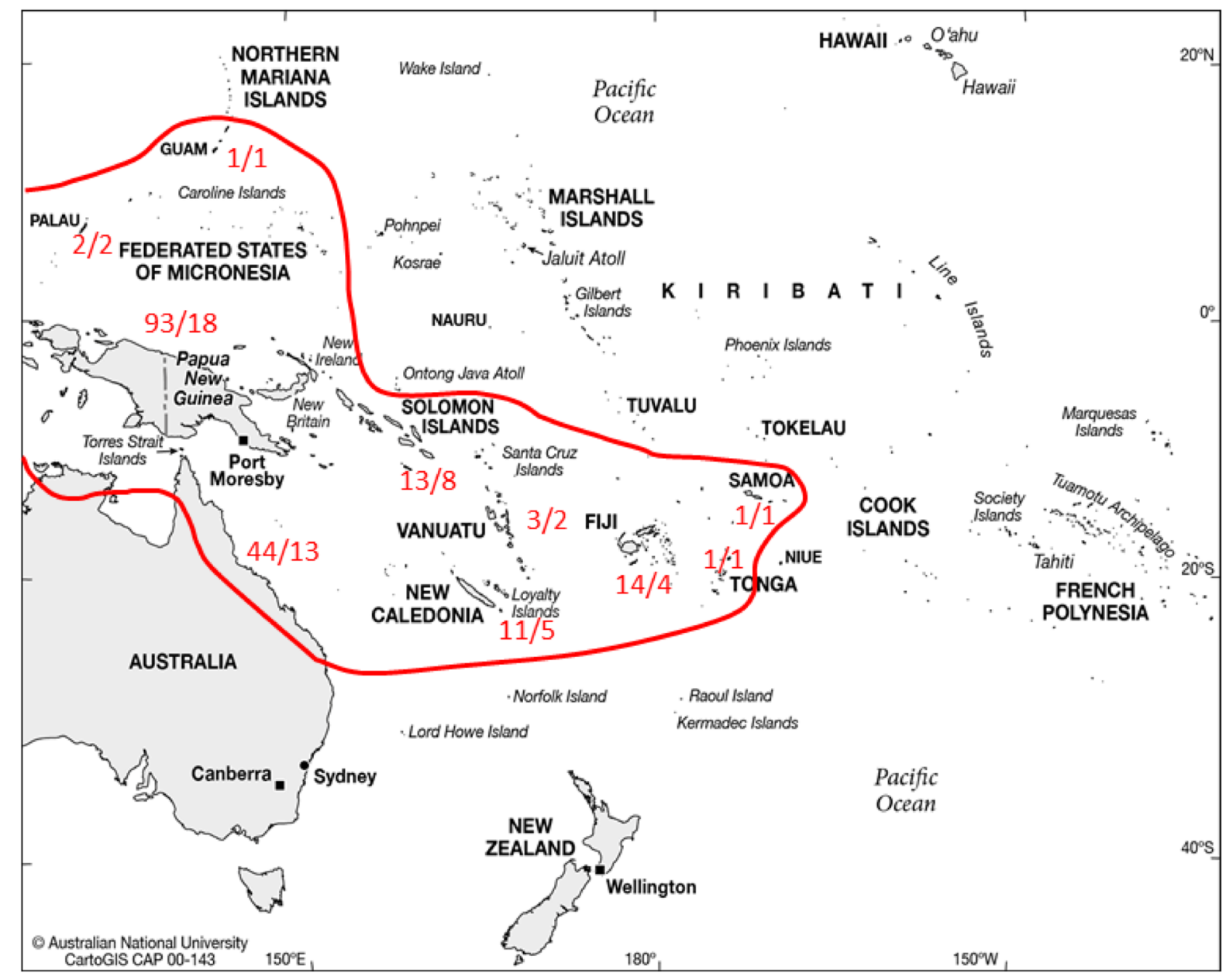

Fig. 20. Regional distribution of the Annonaceae in the Pacific. The numbers next to each island or island group represents the number of native Annonaceae species and genera found there (number of species/number of genera). The numbers for New Guinea remain approximate. The numbers for the Solomon Islands include Bougainville and the Santa Cruz Islands. Base map sourced from CartoGIS, College of Asia and the Pacific, The Australian National University, Australia. 


\section{Regional distribution}

New Caledonia.

\section{Xylopia vitiensis A.C.Sm.}

Sargentia 1: 32 (Smith 1942). - Fissistigma sericeum A.C.Sm., Bulletin of the Bernice P. Bishop Museum 141: 62, fig. 30 (Smith 1936), non Xylopia sericea St.Hil. (Saint-Hilaire 1825). - Type: Fiji, Vanua Levu, Thakaundrove Province, on the southwestern slope of Mt. Mbatini, 28 Nov. 1933, A.C. Smith 669 (holo-: BISH; iso-: GH, K, P, WIS).

\section{Regional distribution}

Fiji.

\section{Notes}

The only part of the holotype in BISH that could not be traced recently was a wood specimen (B. Kennedy, pers. com.).

\section{Discussion}

Of the nine genera in the south-west Pacific, four (Monoon, Polyalthia s. str., Popowia and Uvaria) have not been recorded beyond the Solomons. Drepananthus, Goniothalamus and Xylopia all occur in Fiji, with the latter two also in New Caledonia. Meiogyne, reaching Tonga, and Huberantha, making it to Samoa, are the two genera with the most extensive ranges. Surprisingly, Meiogyne has not been recorded from the Solomons. However, it does occur in Guam and the Northern Marianas making it the Annonaceae genus with the most extensive range in the Pacific. Biogeographical analysis based on molecular phylogenies supports a post mid-Miocene divergence within Huberantha of an AfricaMadagascar clade from the ancestral Asian taxa (Thomas et al. 2015). This represents a dispersal direction counter to the general trand in the family of migration from Africa to Asia (Thomas et al. 2015), and for Huberantha, implies successful long-distance dispersal from Asia to Africa which is also likely to have occurred from mainland Asia to the Pacific. Huberantha species have relatively small fruits and seeds which may facilitate endozoochory, and they are represented in more markedly seasonal climates (Thomas et al. 2015), which may contribute to successful long-distance dispersal. However, it is perhaps more difficult to identify such characteristics in Meiogyne that would explain its success in colonising the Pacific, or, for instance, why Polyalthia s. str., which occurs in seasonal sites and often has small fruits, has not done so.

The Annonaceae in Australia are closely confined to the mesic strip of the north-eastern coast of the continent with a few outliers on the northern promontories (Jessup 2007) (Fig. 20). Success at colonising Australia is no absolute guarantee of success at colonising the Pacific islands. While Huberantha and Meiogyne reach New South Wales on the Australian mainland, reflecting their spread in the Pacific, Uvaria, the third Annonaceae genus to reach New South Wales, is not a great success in the Pacific, with a single species making it to the Solomon Islands. In contrast, genera such as Drepananthus, Goniothalamus and Xylopia, which have been successful in the Pacific are either absent from mainland Australia altogether or have very restricted ranges in northern Queensland.

Uvaria is the only climbing genus of Annonaceae to be found on the Pacific Islands. There is a clear decline in the proportional abundance of Annonaceae climber species compared to tree species as one moves eastwards in Malesia. For instance, while climbers make up more than $25 \%$ of the species in Borneo, they barely exceed $15 \%$ of the species in New Guinea and only a single climber species gets to the Solomons. 
The common pattern of zoochorous dispersal (frugivourous birds and bats in the Pacific) and ecological dependence on forest (intolerance of open, drought-prone habitat) among members of the Annonaceae are likely to make them slow colonisers (Thomas et al. 2015; Stull et al. 2017). The rather 'hit-and-miss' geographical pattern exhibited by the various Annonaceae genera across the south-west Pacific seems to reflect random dispersal events as much as any adaptive colonising ability in these phylogenetic lines. It may be that the poverty of climbing taxa in the Pacific is also a random effect but it could also reflect a more marked dispersal and colonisation limitation in the lianoid, compared to the arborescent, clades.

\section{Acknowledgements}

This work was supported financially by the Bentham-Moxon Trust. Art Whistler very generously allowed us to describe the Huberantha species he discovered on Samoa. Barbara Kennedy (BISH) provided information on specimens at the Bishop Museum. Dr Misako Mishima and Prof. Junji Matsumura very kindly helped with images of the Kanehira specimens in FU. David Johnson and an anonymous reviewer are thanked for their constructive criticism of the paper.

\section{References}

Adanson M. 1763. Familles des plantes. Chez Vincent, Paris. https://doi.org/10.5962/bhl.title.271

Bachman S., Moat J., Hill A., De la Torre J. \& Scott B. 2011. Supporting Red List threat assessments with GeoCAT: Geospatial Conservation Assessment Tool. ZooKeys 150: 117-126. https://doi.org/10.3897/ zookeys. 150.2109

Backer C.A. 1945. Notes on the flora of Java, II. Blumea 5: 490-524.

Baillon H. 1868a. Anonacées. In: Baillon H. (ed.) Histoire des plantes 1: 193-288. L. Hachette et Cie, Paris.

Baillon H. 1868b. Mémoire sur la famille des Anonacées. Adansonia 8: 162-184.

Baillon H. 1871. Stirpes exoticae novae. Adansonia 10: 103-111.

Baillon H. 1874. Stirpes exoticae novae. Adansonia 11: 175-182.

Baker E.G. 1923. Dicotyledons. Polypetalae. Journal of Botany 61 (Suppl.): 2-16.

Beccari O. 1871. Illustrazione di nuove o rare specie di piante Bornensi - Anonacee. Nuovo Giornale Botanico Italiano 3: 177-193.

Beddome R.H. 1864. Contributions to the botany of southern India. Madras Journal of Literature and Science, ser. 3 1: 37-59.

Bentham G. 1863. Flora australiensis. Vol. 1. Lovell Reeve and Co., London.

Blume C.L. 1830. Flora javae nec non insularum adjacentium, 28-29: 57-80, pls 28-39. J. Frank, Brussels.

Boerlage J.G. 1899. Notes sur les Anonacées du jardin botanique de Buitenzorg. Icones Bogorienses $1(2-3): 79-208$.

Browne P. 1756. The civil and natural history of Jamaica in three parts. Gray's-Inn, London.

Burck W. 1911. Anonaceae. Nova Guinea 8: 427-433.

Candolle A.P. de 1828. Prodromus systematis naturalis regni vegetabilis. Vol. 3. Treuttel \& Würtz, Paris.

Candolle A.P. de 1832. Mémoire sur la famille des Anonacées, et en paticulier sur les espèces du pays des Birmans. Mémoires de la Société de Physique et d'Histoire Naturelle de Genève 5: 177-221. 
Chaowasku T., Johnson D.M., van der Ham R.W.J.M. \& Chatrou L.W. 2012. Characterization of Hubera (Annonaceae), a new genus segregated from Polyalthia and allied to Miliusa. Phytotaxa 69: 33-56. https://doi.org/10.11646/phytotaxa.69.1.6

Chaowasku T., Johnson D.M., Van der Ham R.W.J.M. \& Chatrou L.W. 2015. Huberantha, a replacement name for Hubera (Annonaceae: Malmeoideae: Miliusae). Kew Bulletin 70 (2)-23: 1-4.

Chatrou L.W., Pirie M.D., Erkens R.H.J., Couvreur T.L.P., Neubig K.M., Abbott J.R., Mols J.B., Maas J.W., Saunders R.M.K. \& Chase M.W. 2012. A new subfamilial and tribal classification of the pantropical flowering plant family Annonaceae informed by molecular phylogenetics. Botanical Journal of the Linnean Society 169: 5-40. https://doi.org/10.1111/j.1095-8339.2012.01235.x

Däniker A.U. 1931. Ergebnisse der Reise von Dr. A.U. Däniker nach Neu-Caledonien und den Loyalitäts Inseln. 2. Neue Phanerogamen von Neu-Caledonien und den Loyalitäts-Inseln. Vierteljahrsschrift der Naturforschenden Gesellschaft in Zürich 76: 161-162.

Diels L. 1912. Beiträge zur Flora von Papuasien. Serie I. 8. Die Anonaceen von Papuasien. Botanische Jahrbücher für Systematik, Pflanzengeschichte und Pflanzengeographie 49: 113-167.

Diels L. 1915. NeueAnonaceen von Papuasien. Botanische Jahrbücher für Systematik, Pflanzengeschichte und Pflanzengeographie 52: 177-186.

Diels L. 1931. Anonaceae novae. Notizblatt des Botanischen Gartens und Museums zu Berlin-Dahlem 11 (102): 73-86. https://doi.org/10.2307/3994585

Dunal M.F. 1817. Monographie de la famille des Anonacées. Treuttel \& Würtz, Paris.

Endlicher S.L. 1839. Genera plantarum secundum ordines naturalis disposita. Fr. Beck, Vienna.

Florence J. 2004. Flore de la Polynésie française. Vol. 2. IRD Éditions, Paris.

Foreman D.B. 1972. A check list of the vascular plants of Bougainville, with descriptions of some common forest trees. Botany Bulletin, New Guinea 5, Department of Forests, Lae, P.N.G.

Fries R.E. 1953. Verstreute Beobachtungen hinsichtlich der Familie Annonaceae. Arkiv för Botanik 3: 35-42, preprint.

Fries R.E. 1959. Annonaceae. In: Melchior H. (ed.) Die natürlichen Pflanzenfamilien, ed. 2 17a (2): 1-171. Duncker \& Humblot, Berlin.

Gillespie J.W. 1931. New plants from Fiji, II. Bulletin of the Bernice P. Bishop Museum 83: 1-72.

Gray A. 1852. Richella, nov. gen. Proceedings of the American Academy of Arts and Sciences 2: 325.

Gray A. 1854. United States Exploring Expedition. During the years 1838, 1839, 1840, 1841, 1842. Under the command of Charles Wilkes, U.S.N. Vol. 15: Botany. Phanerogamia. C. Sherman, Philadelphia.

Griffith W. 1854. Notulae ad plantas asiaticas. Vol. 4. Bishop's College Press, Calcutta.

Guillaumin A. 1920. Contribution à la Flore de la Nouvelle-Calédonie. Bulletin du Muséum national d'Histoire naturelle 26: 254-261.

Guillaumin A. 1931. Contribution to the flora of the New Hebrides. Plants collected by S.F. Kajewski in 1928 and 1929. Journal of the Arnold Arboretum 12: 221-264.

Guillaumin A. 1932. Matériaux pour la flore de la Nouvelle-Calédonie XXXI. Révision des Anonacées. Bulletin de la Société Botanique de France 79: 689-691. https://doi.org/10.1080/00378941.1932.1083 $\underline{3807}$

Guillaumin A. 1942. Contribution à la Flore de la Nouvelle-Calédonie LXXVII. Plantes de collecteurs divers. Bulletin du Muséum national d'Histoire naturelle, sér. 214 (2): 144-150. 
Guillaumin A. 1948. Flore analytique et synoptique de la Nouvelle-Calédonie Phanerogames. Office de la Recherche Scientifique Coloniale, Paris.

Hemsley W.B. 1895. Oxymitra macrantha. Hooker's Icones Plantarum 24: tabs. 2399-2400.

Heusden E.C.H. van 1994. Revision of Meiogyne (Annonaceae). Blumea 38: 437-511.

Heusden E.C.H. van 1996. The genus Meiogyne (Annonaceae) in New Caledonia: four new combinations. Bulletin du Muséum national d'Histoire naturelle. Section B, Adansonia: botanique, Phytochimie 18 (1-2): 75-83.

Hancock I.R. \& Henderson C.P. 1988. Flora of the Solomon Islands. Research Bulletin 7. Ministry of Agriculture and Lands, Honiara.

Hooker J.D. 1860. XIV. Illustrations of the floras of the Malayan Archipelago and of Tropical Africa. Transactions of the Linnean Society of London 23: 155-172. https://doi.org/10.1111/j.1096-3642.1860. $\underline{\mathrm{tb} 00128 . \mathrm{x}}$

Hooker J.D. \& Thomson T. 1855. Flora indica. Pamplin, London. https://doi.org/10.5962/bhl.title.50109 Hooker J.D. \& Thomson T. 1872. Anonaceae. In: Hooker J.D. (ed.) The flora of British India 1: 45-94. L. Reeve \& Co., London.

Hutchinson J. 1923. Contributions towards a phylogenetic classification of flowering plants. II. The genera of Annonaceae. Bulletin of Miscellaneous Information, Kew 1923: 241-261. https://doi. org $/ 10.2307 / 4120580$

IUCN 2012. IUCN Red List Categories and Criteria:Version 3.1, ed. 2. IUCN, Gland and Cambridge. Jessup L.W. 2007. Annonaceae. In: Wilson A.J.G. (ed.) Flora of Australia 2: 18-57. ABRS, Canberra. Johnson D.M., Munzinger J., Peterson J.A. \& Murray N.A. 2013. Taxonomy and biogeography of the New Caledonian species of Xylopia L. (Annonaceae). Adansonia 35 (2): 207-226. https://doi. org/10.5252/a2013n2a3

Kanehira R. 1931. An enumeration of the woody plants collected in Micronesia, Japanese Mandate (in 1929 and 1930). Botanical Magazine (Tokyo) 45 (534): 271-296. https://doi.org/10.15281/ jplantres1887.45.271

Kanehira R. 1933a. Flora micronesica. South Seas Bureau, Tokyo.

Kanehira R. 1933b. New or noteworthy trees from Micronesia IV. Botanical Magazine (Tokyo) 47 (562): 669-680. https://doi.org/10.15281/jplantres1887.47.669

Katovai E., Edwards W. \& Laurance, W.F. 2015. Dynamics of logging in Solomon Islands: the need for restoration and conservation alternatives. Tropical Conservation Science 8 (3): 718-731. https://doi. org/10.1177/194008291500800309

King G. 1893. The Annonaceae of British India. Annals of the Royal Botanic Garden (Calcutta) 4, Bengal Secretariat Book Depot, Calcutta.

Kuntze O. 1891. Revisio generum plantarum. Vol. 1. Arthur Felix, Leipzig.

Labillardière J.H.H. de 1825. Sertum austro-caledonicum, pars posterior sive ultima. Dominae Huzard, Paris.

Le Thomas A. 1968. Balonga Le Thomas nouveau genre africain de la famille des Annonacées. Adansonia, ser. 2 8: 105-111.

Linnaeus C. 1753. Species plantarum. Vol. 1. Laurentius Salvius, Stockholm.

Linnaeus C. 1759. Systema naturae, ed. 10. Laurentius Salvius, Stockholm. 
Linnaeus f. C. 1782. Supplementum plantarum systematis vegetabilium editionis decimae tertiae, generum plantarum editiones sextae, et specierum plantarum editionis secundae. Orphanotrophe, Braunschweig.

Merrill E.D. 1914. An enumeration of the plants of Guam. Philippine Journal of Science. Section C, Botany 9: 97-155.

Merrill E.D. 1915. Studies on Philippine Annonaceae I. Philippine Journal of Science. Section C, Botany 10: $227-264$.

Merrill E.D. 1919. On the application of the generic name Melodorum of Loureiro. Philippine Journal of Science. Section C, Botany 15: 125-137.

Merrill E.D. 1922. New or noteworthy Bornean plants. Journal of the Straits Branch of the Royal Asiatic Society 85: 151-201.

Miquel F.A.W. 1861. Flora van Nederlandsch Indië. Supplementum primum. Prodromus florae sumatranae. C.G. van der Post, Amsterdam.

Miquel F.A.W. 1865. Anonaceae Archipelagi Indici. Annales Musei Botanici Lugduno-Batavi 2: 1-45.

Moeljono S. 2012. A taxonomic revision of the genus Popowia Endlicher (Annonaceae) in Malesia. PhD thesis, Bogor Agricultural University, Bogor.

Mueller F.J.H. von 1862. Fragmenta phytographiae Australiae. Vol. 3, fasc. 17. J. Ferres, Melbourne.

Mueller F.J.H. von 1863. Fragmenta phytographiae Australiae. Vol. 4. J. Ferres, Melbourne.

Mueller F.J.H. von 1865. Fragmenta phytographiae Australiae. Vol. 5. J. Ferres, Melbourne.

Mueller F.J.H. von 1891. Descriptions of new Australian plants, with occasional other annotations. Victorian Naturalist 7: 180-183.

Muralidharan R., Narasimhan D. \& Balachandran N. 2015. Hubera senjiana is now Huberantha senjiana (Annonaceae). Phytotaxa 217: 200. https://doi.org/10.11646/phytotaxa.217.2.11

Okada H. 1996. New genus and new species of the Annonaceae from the Malesian wet tropics. Acta Phytotaxonomica et Geobotanica 47: 1-9.

Petit-Thouars L.-M.A.A. du 1806. Genera nova madagascariensia. Paris.

Rauschert S. 1982. Nomina nova generica et combinationes nova spermatophytorum et pteridophytorum. Taxon 31: 554-563. https://doi.org/10.2307/1220694

Ridley H.N. 1922. The flora of the Malay Peninsula. Vol. 1. L. Reeve \& Co., London.

Roberty G. 1953. Notes sur la flore de l'Ouest africain. Bulletin de l'Institut Français d'Afrique Noire 15: 1396-1431.

Safford W.E. 1912. Papualthia Mariannae, a new species of Annonaceae from the island of Guam. Journal of the Washington Academy of Sciences 2: 459-463.

Safford W.E. 1913. Pseudannona, a new genus of Annonaceae from the Mascarene Islands; together with notes on Artabotrys uncinatus and its synonymy. Journal of the Washington Academy of Sciences 3: 16-19.

Saint-Hilaire A.F.C.P. de 1825. Plantes usuelles des brasiliens. Part 7. Grimbert, Paris.

Saunders R.M.K. \& Munzinger J. 2007. A new species of Goniothalamus (Annonaceae) from New Caledonia, representing a significant range extension for the genus. Botanical Journal of the Linnean Society 155: 497-503. https://doi.org/10.1111/j.1095-8339.2007.00718.x 
Saunders R.M.K. \& Xue B. 2011. (1992) Proposal to conserve the name Enicosanthum against Monoon (Annonaceae). Taxon 60: 236-237.

Saunders R.M.K. \& Wang J. 2012. Five new nomenclatural combinations in Dasymaschalon and Goniothalamus (Annonaceae). Nordic Journal of Botany 29: 674-676. https://doi.org/10.1111/j.1756$\underline{1051.2011 .01293 . \mathrm{x}}$

Scheffer R.H.C.C. 1876. Énumeration des plantes de la Nouvelle-Guinée, avec déscription des espèces nouvelles. Annales du Jardin botanique de Buitenzorg 1: 1-60.

Scheffer R.H.C.C. 1881. Sur quelques plantes nouvelles ou peu connues de l'Archipel Indien (Annonaceae). Annales du Jardin Botanique de Buitenzorg 2: 1-31.

Schumann K. \& Lauterbach K. 1900. Die Flora der deutschen Schutzgebiete in der Südsee. Gebrüder Borntraeger, Leipzig [“1901”].

Seemann B. 1865. Flora vitiensis. Part 1. L. Reeve \& Co., London.

Setten A.K. van \& Maas P.J.M. 1990. Studies in Annonaceae. XIV. Index to generic names of Annonaceae. Taxon 39: 675-690. https://doi.org/10.2307/1223393

Sinclair J. 1955. A revision of the Malayan Annonaceae. Gardens' Bulletin, Singapore 14: 149-516.

Smith A.C. 1936. Fijian plant studies. Bulletin of the Bernice P. Bishop Museum 141: 1-166.

Smith A.C. 1942. Fijian plant studies, II. Botanical results of the 1940-41cruise of the "Cheng Ho". Sargentia 1: 1-148.

Smith A.C. 1943. Studies on Pacific Island plants - III. New and noteworthy flowering plants from Fiji. Bulletin of the Torrey Botanical Club 70: 533-549. https://doi.org/10.2307/2481400

Smith A.C. 1950. Studies of Pacific Island plants, VI. New and noteworthy plants from Fiji. Journal of the Arnold Arboretum 31: 137-171. https://doi.org/10.5962/bhl.part.25569

Smith A.C. 1978. A precursor to a new flora of Fiji. Allertonia 1: 331-424.

Smith A.C. 1981. Flora vitiensis nova. Vol. 2. Pacific Tropical Botanical Garden, Lawai, Kauai, Hawaii.

Stull G.W., Johnson D.M., Murray N.A., Couvreur T.L.P., Reeger J.E. \& Roy C.M. 2017. Plastid and seed morphology data support a revised infrageneric classification and an African origin of the pantropical genus Xylopia (Annonaceae). Systematic Botany 42: 211-225. https://doi.org/10.1600/036364417X695484

Su Y.C.F. \& Saunders R.M.K. 2009. Evolutionary divergence times in the Annonaceae: evidence of a late Miocene origin of Pseuduvaria in Sundaland with subsequent diversification in New Guinea. BMC Evolutionary Biology 9: 153. https://doi.org/10.1186/1471-2148-9-153

Surveswaran S., Wang R.J., Su Y.C.F. \& Saunders R.M.K. 2010. Generic delimitation and historical biogeography in the early-divergent 'ambavioid' lineage of Annonaceae: Cananga, Cyathocalyx and Drepananthus. Taxon 59: 1721-1734.

Sydow P. 1899. Fungi natalenses. Beiblatt, Hedwigia 38: 130-134.

Tang C.C., Xue B. \& Saunders R.M.K. 2013. A new species of Goniothalamus (Annonaceae) from Palawan, and a new nomenclatural combination in the genus from Fiji. PhytoKeys 32: 27-35. https:// doi.org/10.3897/phytokeys.32.6663

Thomas D.C., Surveswaran S., Xue B., Sankowsky G., Mols J.B., Keßler P.J.A. \& Saunders R.M.K. 2012. Molecular phylogenetics and historical biogeography of the Meiogyne-Fitzalania clade (Annonaceae): generic paraphyly and late Miocene-Pliocene diversification in Australasia and the Pacific. Taxon 61: $559-575$. 
Thomas D.C., Chatrou L.W., Stull G.W., Johnson D.M., Harris D.J., Thongpairojh U. \& Saunders R.M.K. 2015. The historical origins of palaeotropical intercontinental disjunctions in the pantropical flowering plant family Annonaceae. Perspectives in Plant Ecology, Evolution and Systematics 17: 1-16. https://doi.org/10.1016/j.ppees.2014.11.001

Tsiang Y. \& Li P.-T. 1964. Diagnoses of new annonaceous plants from Hainan. Acta Phytotaxonomica Sinica 9: 374-382.

Turner I.M. 2016. New combinations and new synonyms in Asian Annonaceae with a bibliographical note. Webbia 71: 229-232. https://doi.org/10.1080/00837792.2016.1241516

Warburg O. 1891. Beiträge zur Kenntnis der papuanischen Flora. Botanische Jahrbücher für Systematik, Pflanzengeschichte und Pflanzengeographie 13: 230-455.

Warburg O. 1893. Plantae hellwigianae. Beitrag zur Flora von Kaiser Wilhelms-Land. Botanische Jahrbücher für Systematik, Pflanzengeschichte und Pflanzengeographie 18 (1-2): 184-212.

Whistler A. 2011. The rare plants of Samoa. CEPF and CI-Pacific, Apia.

Whitmore T.C. 1966. Guide to the forests of the British Solomon Islands. Oxford University Press, Oxford.

Wight R. 1836. Illustrations of Indian botany. Vol. 1, parts 1-7. J.P. Pharoah, Madras.

Wight R. \& Arnott G.A.W. 1834. Prodromus florae peninsula Indiae orientalis. Parbury, Allen \& co., London.

Xue B., Su Y.C.F., Thomas D.C. \& Saunders R.M.K. 2012. Pruning the polyphyletic genus Polyalthia (Annonaceae) and resurrecting the genus Monoon. Taxon 61: 1021-1039.

Xue B., Thomas D.C., Chaowasku T., Johnson D.M. \& Saunders R.M.K. 2014. Molecular phylogenetic support for the taxonomic merger of Fitzalania and Meiogyne (Annonaceae): new nomenclatural combinations under the conserved name Meiogyne. Systematic Botany 39 (2): 396-404. https://doi. org/10.1600/036364414X680825

Yuncker T.G. 1959. Plants of Tonga. Bulletin of the Bernice P. Bishop Museum 220: 1-283.

Zhou L., Su Y.C.F., Thomas D.C. \& Saunders R.M.K. 2012. 'Out-of-Africa' dispersal of tropical floras during the Miocene climatic optimum: evidence from Uvaria (Annonaceae). Journal of Biogeography 39: 322-335. https://doi.org/10.1111/j.1365-2699.2011.02598.x

Zollinger H. 1858. Uber die Anonaceen des ostindischen Archipels. Linnaea 29: 297-325.

Manuscript received: 15 November 2016

Manuscript accepted: 22 December 2016

Published on: 27 July 2017

Topic editor: Koen Martens

Desk editor: Alejandro Quintanar

Printed versions of all papers are also deposited in the libraries of the institutes that are members of the EJT consortium: Muséum national d'Histoire naturelle, Paris, France; Botanic Garden Meise, Belgium; Royal Museum for Central Africa, Tervuren, Belgium; Natural History Museum, London, United Kingdom; Royal Belgian Institute of Natural Sciences, Brussels, Belgium; Natural History Museum of Denmark, Copenhagen, Denmark; Naturalis Biodiversity Center, Leiden, the Netherlands; Museo Nacional de Ciencias Naturales-CSIC, Madrid, Spain; Real Jardín Botánico de Madrid CSIC, Spain. 